\title{
Small-scale phenotypic differentiation along complex stream gradients in a non- native amphipod
}

\author{
Jonas Jourdan ${ }^{1,2^{*}}$, Kathrin Piro ${ }^{2}$, Alexander Weigand ${ }^{3}$ and Martin Plath ${ }^{4,5}$
}

\begin{abstract}
Background: Selective landscapes in rivers are made up by an array of selective forces that vary from source to downstream regions or between seasons, and local/temporal variation in fitness maxima can result in gradual spatio-temporal variation of phenotypic traits. This study aimed at establishing freshwater amphipods as future model organisms to study adaptive phenotypic diversification (evolutionary divergence and/or adaptive plasticity) along stream gradients.
\end{abstract}

Methods: We collected Gammarus roeselii from 16 sampling sites in the Rhine catchment during two consecutive seasons (summer and winter). Altogether, we dissected $n=1648$ individuals and quantified key parameters related to morphological and life-history diversification, including naturally selected (e.g., gill surface areas) as well as primarily sexually selected traits (e.g., male antennae). Acknowledging the complexity of selective regimes in streams and the interrelated nature of selection factors, we assessed several abiotic (e.g., temperature, flow velocity) and biotic ecological parameters (e.g., conspecific densities, sex ratios) and condensed them into four principal components (PCS).

Results: Generalized least squares models revealed pronounced phenotypic differentiation in most of the traits investigated herein, and components of the stream gradient (PCs) explained parts of the observed differences. Depending on the trait under investigation, phenotypic differentiation could be ascribed to variation in abiotic conditions, anthropogenic disturbance (influx of thermally polluted water), or population parameters. For example, female fecundity showed altitudinal variation and decreased with increasing conspecific densities, while sexual dimorphism in the length of male antennae-used for mate finding and assessment—increased with increasing population densities and towards female-biased sex ratios.

Conclusions: We provide a comprehensive protocol for comparative analyses of intraspecific variation in life history traits in amphipods. Whether the observed phenotypic differentiation over small geographical distances reflects evolutionary divergence or plasticity (or both) remains to be investigated in future studies. Independent of the mechanisms involved, variation in several traits is likely to have consequences for ecosystem functions. For example, leaf-shredding in G. roeselii strongly depends on body size, which varied in dependence of several ecological parameters.

Keywords: Local adaptation, Rapid evolution, Life-history evolution, Thermal pollution, Global warming, Intraspecific divergence, Gammarus roeselii, Aquatic invertebrates, Invasive species

\footnotetext{
* Correspondence: JonasJourdan@googlemail.com

${ }^{1}$ Department of Aquatic Ecotoxicology, Institute for Ecology, Evolution and

Diversity, Goethe University Frankfurt am Main, Frankfurt am Main, Germany

${ }^{2}$ Department of River Ecology and Conservation, Senckenberg Research

Institute and Natural History Museum Frankfurt, Gelnhausen, Germany

Full list of author information is available at the end of the article
}

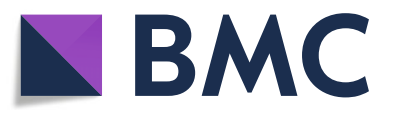

(c) The Author(s). 2019 Open Access This article is distributed under the terms of the Creative Commons Attribution 4.0 International License (http://creativecommons.org/licenses/by/4.0/), which permits unrestricted use, distribution, and reproduction in any medium, provided you give appropriate credit to the original author(s) and the source, provide a link to the Creative Commons license, and indicate if changes were made. The Creative Commons Public Domain Dedication waiver (http://creativecommons.org/publicdomain/zero/1.0/) applies to the data made available in this article, unless otherwise stated. 


\section{Background}

\section{Selective landscapes along complex stream gradients}

Environmental gradients provide a unique opportunity to evaluate the relative importance of various forms of both natural $[1,2]$ and sexual selection $[3,4]$ for creating intraspecific phenotypic variation [1-7]. Changes of environmental conditions can be accompanied by divergence of phenotypic traits when it allows local populations to reach a new fitness peak within a spatially heterogeneous selective landscape $[6,8]$. Studies focusing on environmental gradients acknowledge the multitude of different ecological gradients and described, for instance, gradual variation of abiotic selection factors across latitudinal [9-11], or altitudinal [12] gradients, as well as gradients formed by environmental stressors like temperature [13], salinity $[14,15]$, or acidification $[16,17]$. Other studies focused on biotic selection factors such as predation [18], as well as intra- [19] or inter-specific competition [20]. Beside spatial variation, selection pressures can also vary substantially across time [21, 22].

Streams and the associated limnic ecosystems are shaped by a widespread form of an environmental gradient in which an array of abiotic and biotic selection factors vary systematically in space and time, e.g., from source regions over smaller tributaries to slow-flowing lowland river sections [23-25] or between seasons [21, 23]. Predictable longitudinal changes include, amongst others, changes in primary carbon sources, with allochthonous organic material typically representing the main food source for headwater communities and autotrophic primary production becoming more important at downstream sites [23, 25]. Accumulation of various forms of nutrients usually results in a higher nutrient availability in downstream sections of rivers [23], while in anthropogenically transformed landscapes also pollutants tend to accumulate in downstream sections (e.g., pharmaceuticals [26], pesticides [27], or plastics [28]). Temporal changes in different river sections include, amongst others, flow regimes and water temperatures: source habitats usually show little seasonal fluctuation with respect to abiotic conditions-such as water temperatures [29] - and closely mirror the conditions seen in the groundwater bodies feeding them [23]. The stability of abiotic conditions rapidly decreases with increasing distance from the source(s), especially when the stream is no longer covered by forest canopy, such that water temperatures will attain greater variance due to solar input $[25,30]$. These river sections often experience pronounced fluctuations in abiotic conditions, as they undergo recurrent catastrophic flooding (e.g., after snow melt [31]), or temporal desiccation either during hot/dry seasons [32, 33] or as a result of climate change [34]. Abiotic conditions reattain a more stable state in downstream river portions, where multiple tributaries interconnect to form an extensive wetland system [23, 25].
Despite the generality of some of these characteristics of river gradients at a larger geographical scale [23-25], the situation in reality tends to be more complex, not only because numerous landscape features alter the hydrogeological setting at a local scale $[35,36]$, but also because several forms of anthropogenic stressors [37, 38] contribute to the complexity of selective landscapes along river gradients [23-25]. Obviously, it is close to impossible to empirically capture all abiotic and biotic components characterizing a given stream gradient. Moreover, several factors-including those that were empirically assessed and those not assessed-can be tightly interrelated (e.g., oxygen content and temperature, or the occurrence of certain pollutants [39]). Empirical studies reporting intraspecific trait divergence along stream gradients and ascribing this divergence to one particular component of the gradient are, therefore, prone to overlooking that divergence may have been driven instead by another, interrelated selection factor, or by multiple factors $[6,40]$.

\section{Using amphipods to study phenotypic differentiation along stream gradients}

Our present study, for the first time, reports intraspecific differentiation of morphological and life-history phenotypes along stream gradients in a freshwater amphipod, Gammarus roeselii GERVAIS 1835 [41]. Given their small size and benthic life-style $[42,43]$, amphipods have a low motility compared to, e.g., teleost fishes-which are frequently used in studies on local adaptation along stream gradients [5, 44, 45]-potentially rendering members of this group prime candidates to study adaptive diversification (i.e., evolutionary divergence or adaptive plasticity; see Additional file 1: Material S1 for additional information) over small geographic scales. We evaluated the roles of both natural selection (e.g., low oxygen levels favouring increased gill surface areas [46]; Table 1) and sexual selection for driving divergence in multiple trait suites. In the latter case, divergent selection could arise as an indirect consequence of local differences in population densities (a correlate of mate availability [75]), sex ratios $[59,76]$, or the potential for mate competition $[59,77]$ (Table 1). Nevertheless, the involvement of sexual selection in creating intraspecific phenotypic variation along stream gradients remains understudied $[3,78,79]$.

Acknowledging the complexity of selective regimes in stream gradients [23-25, 37, 38], where multiple selective forces may have complex synergistic, non-additive, or antagonistic effects [80] (potentially overriding certain evolutionary responses, e.g. [81]), we refrain from providing unidirectional predictions for the different trait suites studied herein; an overview of potential predictions can be found in Table 1. We considered physiological traits that are likely to be chiefly under natural selection from abiotic agents of selection (e.g., gill surface areas should vary in 
Table 1 Phenotypic traits assessed in our present study and (unidirectional) predictions for trait divergence along single components of stream gradients

\begin{tabular}{|c|c|c|c|}
\hline Category & Phenotypic trait & $\begin{array}{l}\text { Affected by components of the } \\
\text { river gradient }\end{array}$ & Rationale \\
\hline \multirow[t]{5}{*}{$\begin{array}{l}\text { Body size and condition- } \\
\text { related adult traits }\end{array}$} & \multirow[t]{5}{*}{ Body length } & $\boldsymbol{\nabla}$ Temperature $[47,48],[49,50]^{*}$ & $\begin{array}{l}\text { Increased body size may translate into an } \\
\text { enhanced tolerance to low temperatures. }\end{array}$ \\
\hline & & $\boldsymbol{\Delta}$ Resources $[51,52]$ & $\begin{array}{l}\text { Increased resource availability may result } \\
\text { in larger adult body size, which is often } \\
\text { correlated with increased investment into } \\
\text { reproduction [53]. }\end{array}$ \\
\hline & & $\boldsymbol{\nabla}$ Oxygen [48] & $\begin{array}{l}\text { Oxygen availability is coupled with } \\
\text { temperature regimes and probably a } \\
\text { major mechanistic determinant of growth } \\
\text { and general development. }\end{array}$ \\
\hline & & $\boldsymbol{\Delta}$ Competition [54]* & $\begin{array}{l}\text { Large specimens are more competitive at } \\
\text { high conspecific densities. }\end{array}$ \\
\hline & & $\boldsymbol{\nabla}$ (Micro)pollution [55]* & $\begin{array}{l}\text { Reduced size below sewage treatment } \\
\text { works can be a result of the water containing } \\
\text { endocrine-disrupting chemicals. }\end{array}$ \\
\hline
\end{tabular}

Relatively larger individuals experience higher predation risk than smaller ones.

$\boldsymbol{\Delta}$ Sexual selection [59]*, [60]

Body weight (size-corrected)

$\Delta$ Resources [61]*

- Competition [53]

Predation [62]*, [63]

phenotypic traits
Fecundity (number of offspring

$$
\text { per brood) }
$$

$\Delta$ Resources [58]

A Predation [57]*

$\boldsymbol{\nabla}$ Pollution [64]

$\boldsymbol{\nabla}$ (Micro)pollution [65]

Embryo size

Male pairing success is positively related to body size.

Higher resource availability (usually after leaf fall in autumn and winter) results in increased body condition.

Intraspecific competition results in fewer resources being available per individual to invest into somatic maintenance and reproduction.

Predator cues can induce behavioural alterations (e.g., reduced foraging), resulting in lower body condition.

Higher resource availability allows for more investment into egg production.

Predators increase extrinsic mortality, favouring $r$-selected phenotypes with more, but smaller embryos (see also Embryo size).

Pollution (sewage and heavy metals) derived from industrial and domestic sources reduce fecundity.

Endocrine-disrupting chemicals cause intersexuality in amphipods, leading to a reduced fecundity.

Larger embryo size during winter may be driven by a higher tolerance to low water temperatures.

Absence of cold temperatures in thermally-polluted streams reduces selection for large embryo size.

$\boldsymbol{\nabla}$ Resources [68]*

Under high resource availability embryo size can be reduced, while embryo size should be increased under resource shortage.

The optimal egg size depends on the relationship between juvenile survival and egg size [57]*. The trade-off between offspring size and fecundity [69]* allows females to increase fecundity by producing a few smaller embryos. Smaller size (allowing higher fecundity) is only beneficial if enough offspring survive. 
Table 1 Phenotypic traits assessed in our present study and (unidirectional) predictions for trait divergence along single components of stream gradients (Continued)

\begin{tabular}{|c|c|c|c|}
\hline Category & Phenotypic trait & $\begin{array}{l}\text { Affected by components of the } \\
\text { river gradient }\end{array}$ & Rationale \\
\hline \multirow[t]{2}{*}{ Physiological traits } & \multirow[t]{2}{*}{ Gill surface area } & $\boldsymbol{\nabla}$ Pollution $[70]^{*}$ & $\begin{array}{l}\text { Toxic metals are taken up by aquatic } \\
\text { crustaceans via the gills. Hence, } \\
\text { increased gill area might be } \\
\text { disadvantageous under elevated } \\
\text { heavy metal concentrations. }\end{array}$ \\
\hline & & $\boldsymbol{\nabla}$ Oxygen [46] & $\begin{array}{l}\text { High oxygen supply allows species } \\
\text { to have smaller gill areas. }\end{array}$ \\
\hline \multirow[t]{5}{*}{$\begin{array}{l}\text { Traits used for intrasexual } \\
\text { communication and mate } \\
\text { defense }\end{array}$} & \multirow[t]{3}{*}{ Antennae length } & $\boldsymbol{\Delta}$ Sexual selection $[60,71]^{*}$ & $\begin{array}{l}\text { Male antennae are important for } \\
\text { locating and evaluating potential } \\
\text { mates. }\end{array}$ \\
\hline & & $\boldsymbol{\Delta}$ Male biased sex-ratio/intraspecific density & $\begin{array}{l}\text { Sex ratios affect male mating behaviour } \\
\text { [72] and, therefore, the strength of sexually } \\
\text { selected male traits. Male-male competition } \\
\text { should increase at high population densities } \\
\text { and /or male biased sex-ratios because of } \\
\text { the high encounter rate between competitors. }\end{array}$ \\
\hline & & $\boldsymbol{\Delta}$ (Micro)pollutants [73] $]^{*}$, but see $[74]^{*}$ & $\begin{array}{l}\text { Longer antennae were induced by exposure } \\
\text { to non-ionic surfactant } 4 \text {-nonylphenol [73]; } \\
\text { no effect of estrogen } 17 \text { a-ethinylestradiol } \\
\text { was observed [74]. }\end{array}$ \\
\hline & \multirow[t]{2}{*}{ Gnathopod size } & $\Delta$ Sexual selection $[71]^{*}$ & $\begin{array}{l}\text { Male gnathopods play a central role in } \\
\text { holding/securing the female before and } \\
\text { during copulation (amplexus). }\end{array}$ \\
\hline & & $\boldsymbol{\Delta}$ Male biased sex-ratio $[72]^{*}$ & $\begin{array}{l}\text { Under male biased sex-ratios, male-male } \\
\text { competition increases and males guard } \\
\text { females longer. }\end{array}$ \\
\hline
\end{tabular}

We provide a priori predictions for the direction of evolutionary and/or plastic trait divergence in G. roeselii by agents of natural and sexual selection based on a literature survey including other amphipods (marked by asterisks [*]) and freshwater invertebrates in general. $\mathbf{\Delta}$ Predicted positive association (increasing phenotypic trait values correspond with increasing values of the respective variable); $\boldsymbol{\nabla}$ predicted negative association

dependence of local temperature and oxygen regimes [46]), reproductive life history traits known to be under natural selection from both abiotic and biotic selection factors (brood size/fecundity and offspring size $[18,82,83])$, and traits that are primarily under sexual selection (e.g., size of the male gnathopods, which are involved in mate securing and defense [84]; Table 1).

\section{Intraspecific phenotypic differentiation in invasive amphipods}

In our present study we examined a non-native species that reached Central Europe approximately 150 years ago [41] (see Additional file 1: Material S2 for additional information). While the examination of a species that colonized Central Europe relatively recently already drew the focus of our study towards questions related to contemporary evolution $[85,86]$ or adaptive phenotypic plasticity [87], we included yet another level of questions related to rapid evolutionary change/adaptive plasticity and compared streams with and without anthropogenic thermal pollution (starting approximately 50 years ago $[88,89])$. Studying biotic responses to thermal pollution has become increasingly popular to forecast the potential effects of global warming [90]. Thermal pollution should primarily affect naturally selected traits (e.g., via lower oxygen availability), but could (mediated, e.g., by longer reproductive seasons) also affect the strength and direction of sexual selection (Table 1). Given that studies on inter- and intra-specific body size variation have been at the forefront of research on climate-related evolution for centuries (Bergman's rule, originally formulated for endotherms [91] but partly also applied to ectotherms [47]), we assessed body size as another dependent variable (Table 1).

Our study was motivated by the idea that freshwater amphipods-including invasive species or those that expanded their distribution ranges relatively recently-could be established as a future model for several questions in evolutionary ecology, especially questions related to local adaptation [6, 8], contemporary evolution [85] or adaptive phenotypic plasticity [87], life-history evolution [18, 82], and climate change biology [92]. Our present study is centred on two major questions:

(1) Do we find small-scale phenotypic differentiation in non-native G. roeselii approximately 150 years upon their arrival in Central Europe [41] along repeated river gradients? To answer this question, we sampled amphipods from 16 sites along two streams in Germany (Fig. 1) and assessed an array of phenotypic traits (Table 1). 


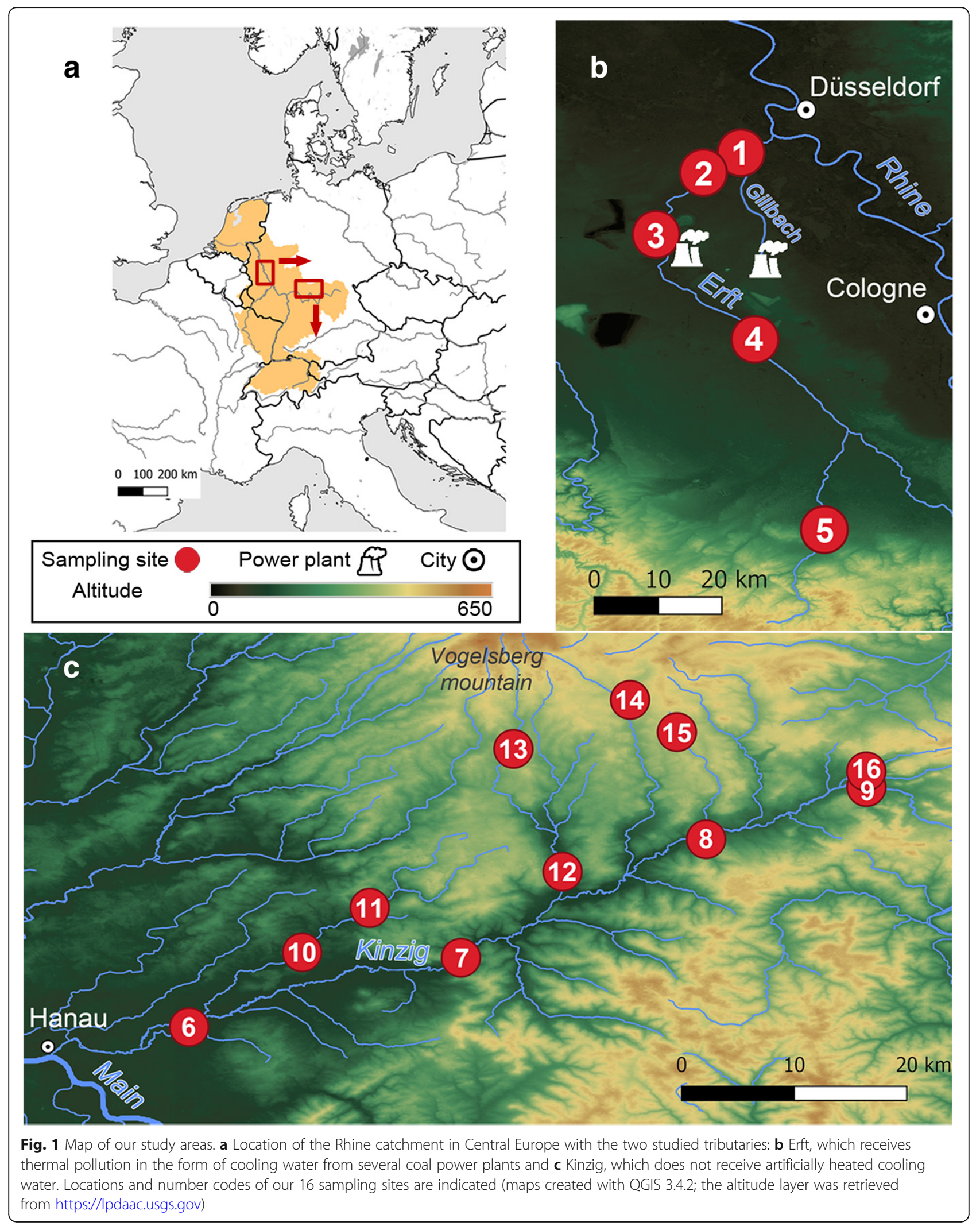


(2) If phenotypic differentiation is uncovered, can we ascribe at least parts of this variation to known drivers of both natural and sexual selection processes (or triggers of adaptive plasticity), including selection factors arising from anthropogenic activities (Table 1)?

\section{Methods}

\section{Study species and sample collection}

We focused on a 'naturalised' [93] non-native species, Gammarus roeselii, which has spread throughout Central Europe and established stable populations since the nineteenth century [41]. Gammarus roeselii is usually considered as a downstream-adapted species [94, 95]. However, several populations in downstream sections of Central European streams were recently replaced by the more recent invaders Dikerogammarus villosus and Echinogammarus ischnus [96-98]. On the other hand, G. roeselii is nowadays found in at least some Central European first order streams at altitudes above $400 \mathrm{~m}$ (this study).

We collected specimens in two subcatchments within the Rhine catchment (Fig. 1). The Erft is located in a heavily exploited, urbanized area and in downstream sections receives cooling water from several nearby coal power plants $[88,89]$, which significantly increases average water temperatures (mean $\pm \mathrm{SD}$ during winter: $6.1 \pm 1.1^{\circ} \mathrm{C}$ at thermally non-polluted sites and $12.4 \pm 1.2^{\circ} \mathrm{C}$ at thermally polluted sites; during summer: $17.5 \pm 3.0^{\circ} \mathrm{C}$ at thermally nonpolluted sites and $23.7 \pm 0.3{ }^{\circ} \mathrm{C}$ at thermally polluted sites), while our sampling sites in the Kinzig are located within a long-term ecological research area (LTER [99]), and its tributaries do not receive thermally polluted water (Additional file 1: Table S1). We caught amphipods using a multi-habitat kick-sampling method [100]. To account for potential seasonal variation of the traits considered here, we sampled all sites twice, once in February (winter sampling) and once in May of 2017 (summer sampling). All captured specimens were immediately preserved in $96 \%$ ethanol until they were processed in the laboratory. As G. roeselii has been reported to occasionally co-occur with the congeners G. fossarum and G. pulex [94, 101], we verified species identity of all specimens under a stereomicroscope (Olympus SZX12 with an Olympus DF PLFL 0.5X PF objective) using standard identification keys [102, 103]. Altogether, we dissected $n=1648$ G. roeselii from 16 sampling sites $(n=373$ from thermally polluted and $n=1275$ from thermally nonpolluted sites; Additional file 1: Table S3).

\section{Environmental parameters}

We assessed a range of environmental variables that are frequently used to characterize stream gradients [23-25] and show gradual variation along the examined river stretches (Additional file 1: Table S1). At each site, we measured water temperature $\left[{ }^{\circ} \mathrm{C}\right]$ (using a WTW Multi 340i, TetraCon $\left.{ }^{\circ} 325\right)$, flow velocity $\left[\mathrm{m} \mathrm{s}^{-1}\right]$ using a portable flowmeter (P770, Dostmann electronic $\mathrm{GmbH}$ ), oxygen content [mg L ${ }^{-1}$ ] (WTW Multi 340i, CellOx $\left.{ }^{\circ} 325\right)$, and conductivity $\left[\mu \mathrm{cm}^{-1}\right]$ (WTW Multi 340i, TetraCon ${ }^{\circ} 325$ ). We estimated average stream depth at our sampling sites as falling into one of three categories $(<0.5 \mathrm{~m}, 0.5-1 \mathrm{~m},>1 \mathrm{~m})$. Similarly, we categorized average stream width as $<7 \mathrm{~m}, 7-12 \mathrm{~m}$, or $>13 \mathrm{~m}$. Altitudinal information [m above sea level] was extracted from Google Earth (http://earth.google.com/). We estimated conspecific population densities by counting all specimens caught by two persons that applied multi-habitat kick sampling [100] for $30 \mathrm{~min}$ in a river stretch of $50 \mathrm{~m}$. We categorized population densities as low (0-50 individuals), medium (51-200 individuals), or high ( $>200$ individuals). Based on the obtained sample of $G$. roeselii specimens, we calculated sex-ratios (number of females/number of males) for each sampling site. Since several explanatory variables showed strong intercorrelations (Table 2), we

Table 2 Results of a factor reduction procedure (PCA) on 11 environmental parameters measured at our 16 sampling sites

\begin{tabular}{|c|c|c|c|c|}
\hline & Env. PC 1 & Env. PC 2 & Env. PC 3 & Env. PC 4 \\
\hline Stream width $[\mathrm{m}]$ & 0.89 & -0.15 & -0.01 & -0.02 \\
\hline Stream depth $[\mathrm{m}]$ & 0.79 & -0.32 & 0.22 & -0.04 \\
\hline Water temperature $\left[{ }^{\circ} \mathrm{C}\right]$ & 0.39 & 0.01 & 0.58 & 0.49 \\
\hline Oxygen content $\left[\mathrm{mg} \mathrm{L}^{-1}\right]$ & 0.23 & 0.10 & -0.85 & 0.20 \\
\hline Flow velocity $\left[\mathrm{m} \mathrm{s}^{-1}\right]$ & 0.06 & 0.59 & 0.01 & -0.19 \\
\hline Conductivity $\left[\mu \mathrm{S} \mathrm{cm}^{-1}\right]$ & 0.80 & 0.27 & -0.21 & 0.14 \\
\hline Density (catch-per-unit effort) & 0.20 & 0.61 & 0.40 & 0.23 \\
\hline Altitude $[\mathrm{m}]$ & -0.83 & -0.16 & 0.15 & 0.05 \\
\hline Sex ratio (females/ males) & -0.06 & 0.77 & -0.24 & 0.01 \\
\hline Thermal pollution (yes/ no) & 0.79 & 0.22 & 0.14 & 0.11 \\
\hline Season (summer/ winter) & -0.04 & -0.10 & -0.10 & 0.93 \\
\hline
\end{tabular}

Shown are PC axes ('environmental PCs') with eigenvalues > 1.0; axes were varimax-rotated using the Kaiser Normalization method. Variables with |axis loading $\mid \geq 0.5$ are highlighted in bold font 
applied a factor reduction (PCA) using the Varimax option (based on the Kaiser normalization rotation method [104]) as implemented in SPSS 23. The four resulting rotated principal components (henceforth called 'environmental PCs') with eigenvalues $>1.0$ were used as explanatory variables for all further analyses (for axis loadings see Table 2). Cumulatively, they explained $71.8 \%$ of the total variation (PC 1 explained 32.8\%, PC 2: 14.5\%, PC 3: $12.9 \%$ and PC4 11.5\%).

\section{Life history and morphometric data}

We collected information on male and female lifehistories (see Additional file 1: Material S3 for additional information) and morphological traits from 50 to 128 individuals per population (Additional file 1: Table S3). All measurements of distances or areas were conducted under a stereomicroscope (OLYMPUS SZX12) with an OLYMPUS DF PLFL 0.5X PF objective and an attached OLYMPUS SC30 camera connected to a computer. We used the software $\mathrm{Cell}^{\wedge} \mathrm{A}$ (Olympus) for all linear and area measurements.

\section{Sexing, adult body size and weight}

Specimens were sexed according to external sexual characteristics: males were identified by the presence of genital papillae (Fig. 2a) which lie ventrally in the middle of the bases of the 5th pereopods [103]. Female gammaridean amphipods usually have four pairs of oostegites between pereopods 2-6 [105]. In some cases, intersexual individuals [106] with both genital papillae and oostegites were observed (Fig. 2b; see Additional file 1: Material S4 for additional information and a posteriori analyses on data from our present study).

We determined each specimen's body length [mm] from the tip of the rostrum to the telson tip (Fig. 2c). To do so, alcohol-stored specimens were placed in lateral position in a wax-filled Petri dish and were carefully straightened using preparation needles. We ensured that all specimens were similarly stretched before measuring their body length. We also measured head capsule length as an alternative proxy for body size [107]. However, both traits were strongly collinear (Pearson's $r=0.92$; Additional file 1: Figure S1), and so we used body length throughout. Before we assessed somatic dry weight $[\mathrm{mg}]$, we removed all eggs from the female marsupium, after which we dried specimens for $24 \mathrm{~h}$ at $60^{\circ} \mathrm{C}$ in a drying oven (Heraeus Type B5042). We stored dried individuals in a desiccator containing dry silica gel to prevent water-uptake while cooling down to room temperature. Afterwards, we weighted specimens to the nearest $0.1 \mathrm{mg}$ on a microscale (SI-234 Denver Instrument).

\section{Physiological traits}

We additionally measured gill surface areas. Gills are a multi-functional organ, involved in several physiological processes, tightly linked to physiological homeostasis of oxygen $/ \mathrm{CO}_{2}$ concentrations [108], osmoregulatory ion transport [109] and excretion of nitrogenous waste products [109]. Furthermore, toxic metals are taken up by aquatic crustaceans via the gills, such that the gills play an important role in mediating the response of aquatic amphipods to contaminants [109, 110]. Dissecting the delicate gills of amphipods is a tedious and timeconsuming task. We, therefore, decided to concentrate on one sex and measured gill surface areas in males only, even if this introduces a potential bias and prevented us from detecting potential sex-specific variation.

We placed males in a dorsal position onto agarose gel and fixed them with two fine needles, upon which we carefully removed the gills from the right body site at their base using a fine preparation needle. We photographed the gills and measured their circumference (Fig. 2d). The area of each gill was determined using the image analysis software Cell^A (Olympus). We summed data from all six gills per individual as a proxy of the respiratory surface area $\left[\mathrm{mm}^{2}\right]$. However, our method did not allow us to detect potential changes in secondary and tertiary lamella [111], which might be an alternative phenotypic response to increase the overall respiratory surface area.

\section{Traits used for inter-sexual communication and mate guarding}

Male gammarids use their antennae during mate assessment $[60,71]$. Accordingly, their antennae tend to be sexually dimorphic [112], and the length of the antennae in gammarids [71, 113] and other crustaceans [60] can show variation between populations. We carefully removed both pairs of antennae of all individuals (males and females) at their base using a fine preparation needle. Antenna length $[\mathrm{mm}]$ was assessed by measuring the distance from the base of the first pedunculus to the tip of the flagellum (Fig. 2e). We calculated mean values from the antennae on the left and right body sides.

Gnathopods play a central role for holding/securing the female before and during copulation (called amplexus [105]), which includes defending the female from rivals that attempt to take over the female [72, 84]. To assess potential population variation in this trait [113], we measured the size $[\mathrm{mm}]$ of the $1^{\text {st }}$ gnathopod on the right body side in all males. To do so, the gnathopod was carefully removed and photographed. We drew a virtual orientation line at the base of the propodus and measured the distance between the base of the propodus to the tip of the dactylus (Fig. 2f). 

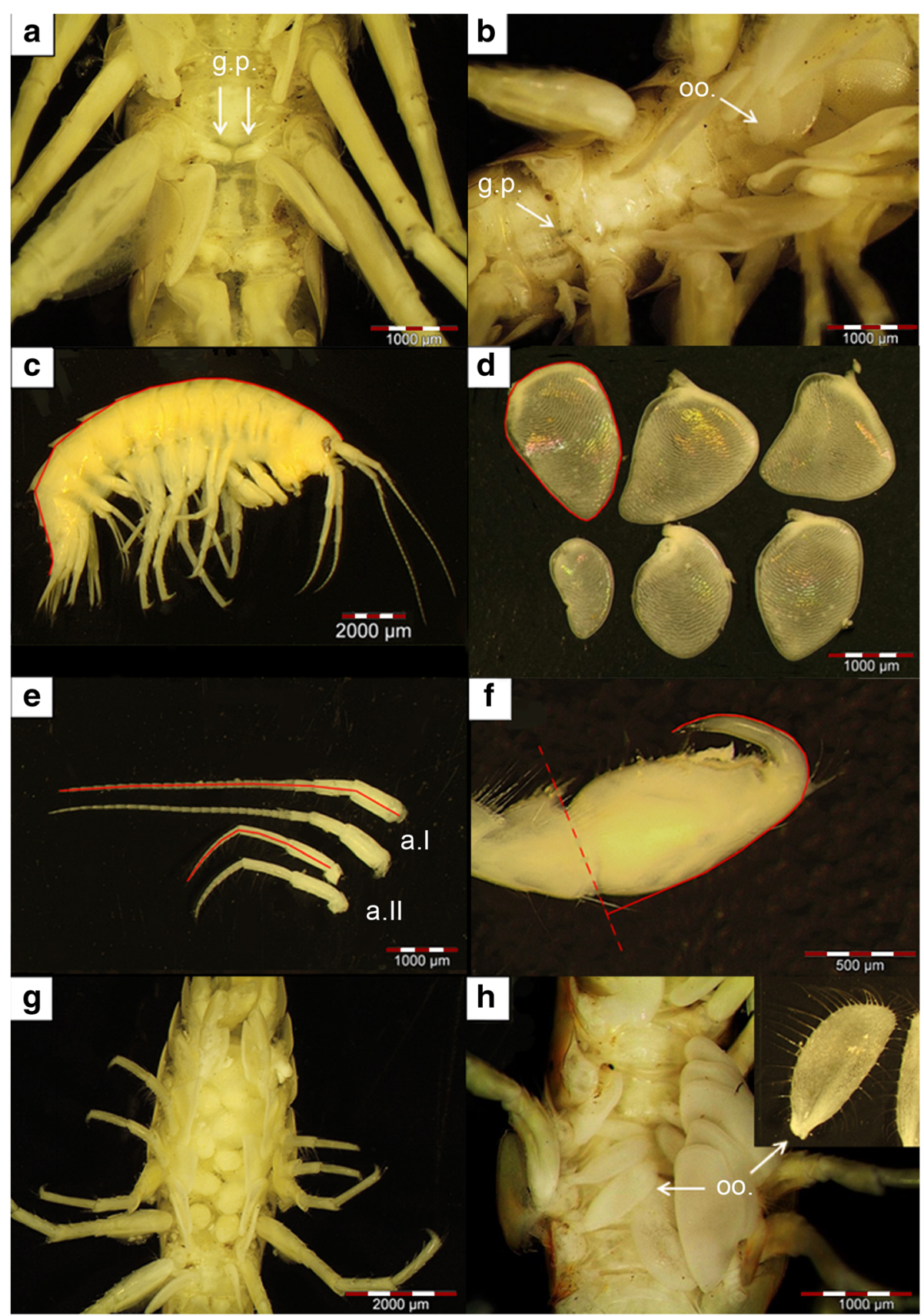

Fig. 2 Overview of morphological characteristics assessed in this study. a Males were identified by the presence of genital papillae (g.p.). b Intersexual individuals show female (oostegites; oo.) and male (genital papillae; g.p.) sexual characteristics. The following parameters we measured as distances or areas (marked by red lines) and used to assess population variation in c body length, $\mathbf{d}$ gill area (circumference of the six gills on the right body site; considered herein as a 'physiological trait'), e lengths of the $1^{\text {st }}$ antennae (a.l) and the smaller $2^{\text {nd }}$ antennae (a.II), from the first pedunculus to the tip of the flagellum, and $\mathbf{f}$ size of the $1^{\text {st }}$ gnathopod on the right body size of males (length from the tip of the dactylus to the base of the propodus). $\mathbf{g}$ Females carry their developing broods in an external brood pouch that is formed by (h) four pairs of oostegites (oo.)

\section{Offspring-related phenotypic traits}

For each female, we determined fecundity by carefully removing all eggs from the brood pouch (the marsupium [66, 105]; Fig. 2g) with a fine brush and counting them. Data from females harbouring stage 7 embryos (see below) were excluded, as some of the juveniles may already have left the marsupium. To estimate egg volumes $\left[\mathrm{mm}^{3}\right]$, we measured the longest and shortest axis of each egg in 2D view and used an ellipsoid formula to approximate egg volume (see [67]). We identified 
embryonic developmental stages according to earlier descriptions for Gammarus spp. [67, 108, 114]. A detailed description can be found in Additional file 1: Material S5, and exemplary photos are shown in Fig. 3.

\section{Statistical analyses}

We asked whether and how environmental parameters used to characterize stream gradients and condensed into principal components (Table 2) drive divergence of

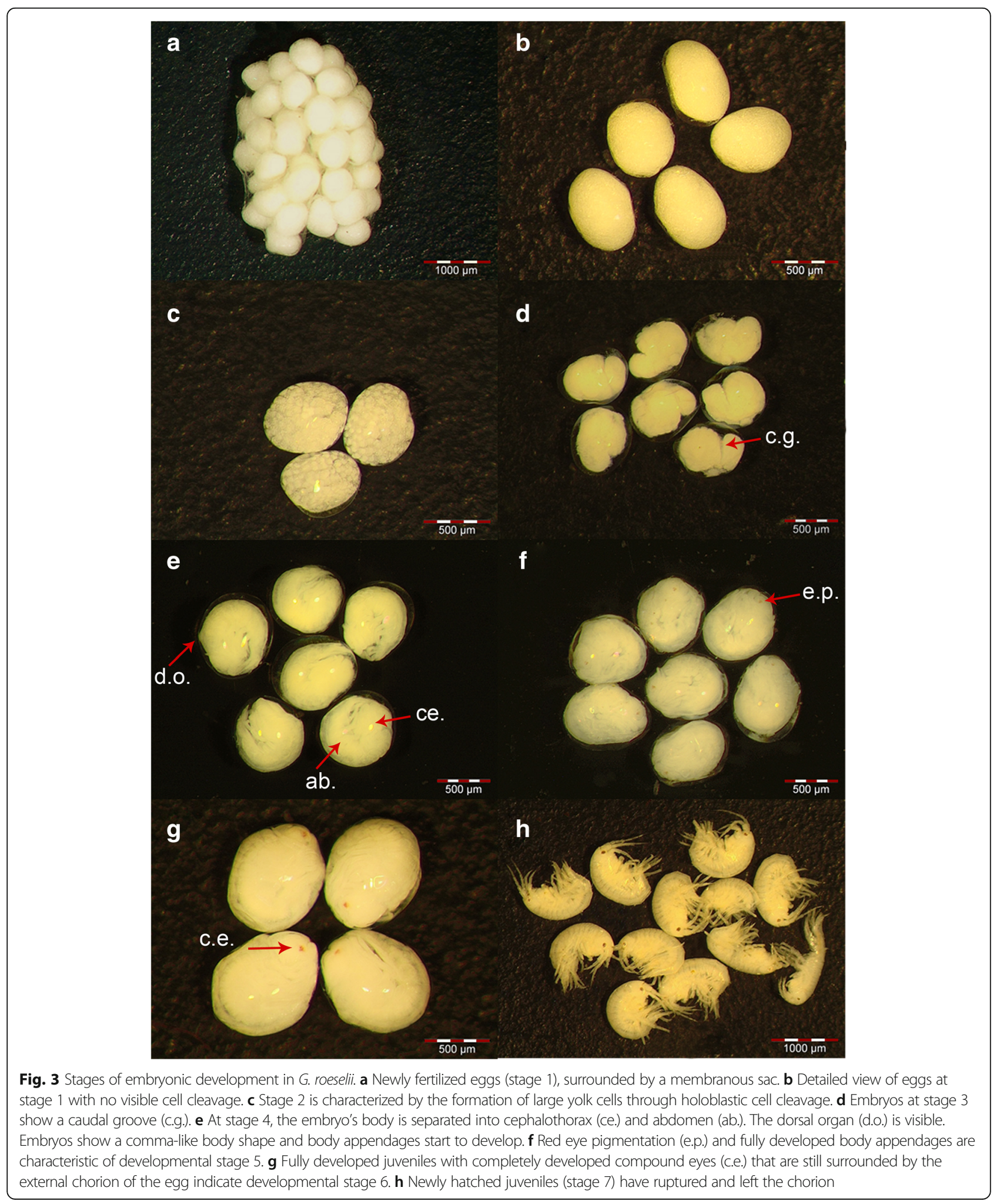


multiple phenotypic traits. To this end, we applied generalized least squares models (GLS) using the glsfunction, implemented in the nlme package in $\mathrm{R}$ [115] fitted by maximum-likelihood estimation and assuming a Gaussian error distribution. To account for spatial autocorrelation, we fit our GLS models with an autoregressive (AR-1) correlation structure [116]. Each of the following variables was modelled separately: 'body length', 'dry weight, 'length of $1^{\text {st }}$ antennae,' and 'length of $2^{\text {nd }}$ antennae'. For females, we additionally analysed 'fecundity' and 'egg volume' and for males 'gill area' and 'gnathopod size'. We included the explanatory variables 'environmental PCs $1-4$,' 'sex' (in all cases where data were available from both sexes) and 'body length' to account for ontogenetic changes in trait values. For the model on egg volume, we additionally considered 'developmental stage' as an explanatory variable to account for ontogenetic changes in egg/embryo size during development. The statistical significance of explanatory variables in the linear models was evaluated by Type III ANOVAs (using the Anovafunction implemented in the car package [117]). Assumptions of normality of residuals was assessed visually by inspecting QQ-plots and plots of residuals vs. fitted values (Additional file 1: Figure S3). In the case of significant effects, we calculated and visualized predicted marginal effects of environmental variables on dependent variables using the ggeffects package [118]. All statistical analyses were performed in R 3.5.1 [119].

\section{Results}

Inspection of axis loadings of the four principal components (PCs) retained from our factor reduction of various environmental parameters (Table 2) allows the following interpretation: PC 1 reflected variation from upstream to downstream conditions, with higher PC-scores being associated with greater stream width, stream depth, conductivity and thermal pollution, while altitude had a negative axis loading. PC 2 captured variation in flow velocity, conspecific densities and sex ratios, whereby positive values represented fast-flowing sites with high densities and female-biased sex-ratios. PC 3 received high axis loadings from water temperatures and oxygen content and could be interpreted as describing the gradient from cold, well-oxygenated sites towards warmer sites with lower oxygen content. Finally, PC 4 captured seasonal variation between summer (negative values) and winter samplings (positive values). In the following, we will present significant outcomes of trait-wise generalized least squares models (Tables $3,4,5$ ) in light of the information captured by the four PCs that served as explanatory variables.

\section{Body size and condition-related adult traits}

Adult body size decreased significantly from upstream to downstream sites (i.e., along environmental PC 1; $X^{2}=23.92, p<0.001$; Table 3a; Fig. 4a) and with increasing conspecific densities (PC 2; $\chi^{2}=4.0, p=0.046$; Fig. 4b). Likewise, adult body weight decreased significantly along environmental PC $2\left(\chi^{2}=9.89, p=0.002\right.$; Table 3b; Fig. 4c) and showed seasonal fluctuation, with greater body weight being observed in winter ( $\mathrm{PC} \mathrm{4}$; $\chi^{2}=6.33, p=0.012$; Fig. 4 d).

\section{Physiological traits}

Gill surface areas decreased from upstream to downstream conditions (environmental PC 1; $\chi^{2}=15.20$, $p<0.001$; Table 3c; Fig. 5a). Moreover, gills surface areas were greater during winter than summer ( $\mathrm{PC} \mathrm{4;}$ $\chi^{2}=10.37, p=0.001$; Fig. 5b).

Table 3 Results of generalized least squares models on body size/condition-related phenotypic and physiological traits of adult G. roeselii

\begin{tabular}{|c|c|c|c|c|c|c|c|c|c|}
\hline & \multicolumn{3}{|c|}{ (a) Body length } & \multicolumn{3}{|c|}{ (b) Dry weight } & \multicolumn{3}{|c|}{ (c) Gill surface area } \\
\hline & $\overline{d f}$ & $x^{2}$ & $p$ & $\overline{d f}$ & $x^{2}$ & $p$ & $d f$ & $x^{2}$ & $p$ \\
\hline Body length (covariate) & - & - & - & 1 & 4524.10 & $<0.001$ & 1 & 2013.60 & $<0.001$ \\
\hline Sex & 1 & 39.92 & $<0.001$ & 1 & 0.12 & 0.73 & - & - & - \\
\hline Environmental PC 1 & 1 & 23.92 & $<0.001$ & 1 & 1.53 & 0.22 & 1 & 15.20 & $<0.001$ \\
\hline Sex $\times$ env. PC 1 & 1 & $<0.001$ & 0.98 & 1 & 2.10 & 0.15 & - & - & - \\
\hline Environmental PC 2 & 1 & 4.00 & 0.046 & 1 & 9.89 & 0.002 & 1 & 0.84 & 0.36 \\
\hline Sex $\times$ env. $P C 2$ & 1 & 1.08 & 0.30 & 1 & 1.77 & 0.18 & - & - & - \\
\hline Environmental PC 3 & 1 & 2.47 & 0.12 & 1 & 0.01 & 0.91 & 1 & 0.00 & 0.99 \\
\hline Sex $\times$ env. $P C 3$ & 1 & 1.87 & 0.17 & 1 & 0.99 & 0.32 & - & - & - \\
\hline Environmental PC 4 & 1 & 0.71 & 0.40 & 1 & 6.33 & 0.012 & 1 & 10.37 & 0.001 \\
\hline Sex $\times$ env. PC 4 & 1 & 0.09 & 0.77 & 1 & 1.72 & 0.19 & - & - & - \\
\hline
\end{tabular}

Shown are the results of three independent models using (a) adult body size, (b) body weight, assessed after drying samples overnight (in both sexes) and (c) gill surface areas (only males) as the dependent variables. Environmental PCs (Table 2), as well as sex and body length (where applicable) were coded as independent (explanatory) variables. Significant effects are shown in bold 
Table 4 Results of generalized least squares models on phenotypic traits used for mate assessment and mate defence

\begin{tabular}{|c|c|c|c|c|c|c|c|c|c|}
\hline & \multicolumn{3}{|c|}{ (a) $1^{\text {st }}$ Antennae } & \multicolumn{3}{|c|}{ (b) $2^{\text {nd }}$ Antennae } & \multicolumn{3}{|c|}{ (c) Gnathopod length } \\
\hline & $\overline{d f}$ & $x^{2}$ & $p$ & $\overline{d f}$ & $x^{2}$ & $p$ & $\overline{d f}$ & $x^{2}$ & $p$ \\
\hline Body length & 1 & 4388.92 & $<0.001$ & 1 & 4912.87 & $<0.001$ & 1 & 0.66 & 0.42 \\
\hline Sex & 1 & 152.65 & $<0.001$ & 1 & 1381.67 & $<0.001$ & - & - & - \\
\hline Environmental PC 1 & 1 & 63.08 & $<0.001$ & 1 & 48.98 & $<0.001$ & 1 & 0.01 & 0.91 \\
\hline Sex $\times$ env. PC 1 & 1 & 0.08 & 0.78 & 1 & 6.64 & 0.010 & - & - & - \\
\hline Environmental PC 2 & 1 & 0.35 & 0.55 & 1 & 2.89 & 0.089 & 1 & 0.71 & 0.40 \\
\hline Sex $\times$ env. PC 2 & 1 & 5.66 & 0.017 & 1 & 0.05 & 0.83 & - & - & - \\
\hline Environmental PC 3 & 1 & 34.23 & $<0.001$ & 1 & 11.39 & 0.001 & 1 & 0.33 & 0.57 \\
\hline Sex $\times$ env. $P C 3$ & 1 & 0.10 & 0.76 & 1 & $<0.001$ & 0.96 & - & - & - \\
\hline Environmental PC 4 & 1 & 39.96 & $<0.001$ & 1 & 13.62 & $<0.001$ & 1 & $<0.001$ & 0.98 \\
\hline Sex $\times$ env. PC 4 & 1 & 0.55 & 0.46 & 1 & 0.54 & 0.46 & - & - & - \\
\hline
\end{tabular}

We assessed the following dependent variables: (a) length of the $1^{\text {st }}$ and (b) $2^{\text {nd }}$ antennae (which males use for mate detection and assessment) in both sexes. (c) Gnathopod size (used by males during precopulatory mate guarding, called amplexus) was assessed only in males. Environmental PCs (Table 2), body length and sex (where applicable) served as predictor variables. Significant effects are shown in bold

Traits involved in intersexual communication and mate guarding

We found a pronounced sexual dimorphism in the length of the $1^{\text {st }}\left(\chi^{2}=152.65, p<0.001\right)$ and $2^{\text {nd }}$ antennae $\left(\chi^{2}=\right.$ 1381.67, $p<0.001$; Table 4$)$, with males possessing longer antennae than females. Moreover, antennae length showed gradual variation along all four environmental PCs (see significant effects of PC 1 - PC 4; Table 4). Specifically, both the $1^{\text {st }}\left(X^{2}=63.08, p<0.001\right.$; Fig. $\left.6 a\right)$ and $2^{\text {nd }}$ antennae $\left(\chi^{2}=48.98, p<0.001\right.$; Fig. $\left.6 \mathrm{~b}\right)$ became longer along environmental PC 1 . The significant interaction term of 'sex $\times$ environmental PC 2' reflects that the length of the $1^{\text {st }}$ antennae of males increased to a greater extent along PC 2 (i.e., with increasing population densities and increasingly female-biased sex ratios) than those of females $\left(x^{2}=5.66, p=0.017\right.$; Fig. 6c). Both antennae increased along environmental PC $3\left(1^{\text {st }}\right.$ antennae: $x^{2}=34.23, p<$ 0.001; Fig. 6d; $2^{\text {nd }}$ antennae: $\chi^{2}=11.39, p=0.001$; Fig. 6e) and were longer during winter compared to our summer sampling (PC 4; $1^{\text {st }}$ antennae: $\chi^{2}=39.96, p<0.001$; Fig. 6f; $2^{\text {nd }}$ antennae: $\chi^{2}=13.62, p=0.001$; Fig. 6 g). Notably, we

Table 5 Results of generalized least squares models on reproductive life-history traits in females

\begin{tabular}{|c|c|c|c|c|c|c|}
\hline & \multicolumn{3}{|c|}{ (a) Fecundity } & \multicolumn{3}{|c|}{ (b) Egg size } \\
\hline & $\overline{d f}$ & $x^{2}$ & $p$ & $\overline{d f}$ & $x^{2}$ & $p$ \\
\hline Female body length & 1 & 207.72 & $<0.001$ & 1 & 13.56 & $<0.001$ \\
\hline Developmental stage & - & - & - & 1 & 1784.89 & $<0.001$ \\
\hline Environmental PC 1 & 1 & 20.08 & $<0.001$ & 1 & 1.47 & 0.23 \\
\hline Environmental PC 2 & 1 & 78.20 & $<0.001$ & 1 & 3.05 & 0.081 \\
\hline Environmental PC 3 & 1 & 2.95 & 0.086 & 1 & 0.00 & 0.98 \\
\hline Environmental PC 4 & 1 & 1.43 & 0.23 & 1 & 0.02 & 0.89 \\
\hline
\end{tabular}

Two independent models considered (a) egg number per brood (fecundity) and (b) egg size as the dependent variables, while environmental PCs (Table 2), body length and developmental stage (where applicable) served as predictor variables. Significant effects are shown in bold. did not find significant divergence in male gnathopod length along environmental gradients (Table 4c).

\section{Reproductive characteristics}

Female fecundity (numbers of eggs per brood)-size-corrected by inclusion of the covariate 'female body length' (Table 5a)-decreased significantly from up- to downstream sites (i.e., along environmental PC $1 ; \chi^{2}=20.08$, $p<0.001$; Fig. 7a) and with higher conspecific densities (PC 2; $x^{2}=78.20, p<0.001$; Fig. $7 b$ ). Egg size did not show gradual variation along any of the components of the stream gradient (Table $5 b$ ).

\section{Discussion}

We found phenotypic differentiation among populations of $G$. roeselii occurring along the two river stretches examined in this study, including body size and weight, physiological traits (gill surface areas), reproductive life-history traits, and sexually selected morphological traits. Our study does not allow inferences regarding the relative roles of evolved differences (local adaptation) and phenotypic plasticity (Additional file 1: Material S1). Still, our analyses suggest that spatial variation in ecological conditions along the examined stream gradients drives the observed intraspecific differentiation over small geographic scales (i.e., within and between river catchments).

\section{Ecological significance of phenotypic differentiation}

What are the potential ecological implications of our findings? Recent years have seen a steep increase in numbers of publications that either analyse empirical data (e.g., [120]) and/or use mathematical modelling (e.g., [121]) to understand ecological phenomena over large geographic scales (macroecology [122]). These approaches, however, usually treat species as "evolutionarily inert" entities with fixed (species-specific) ecological 


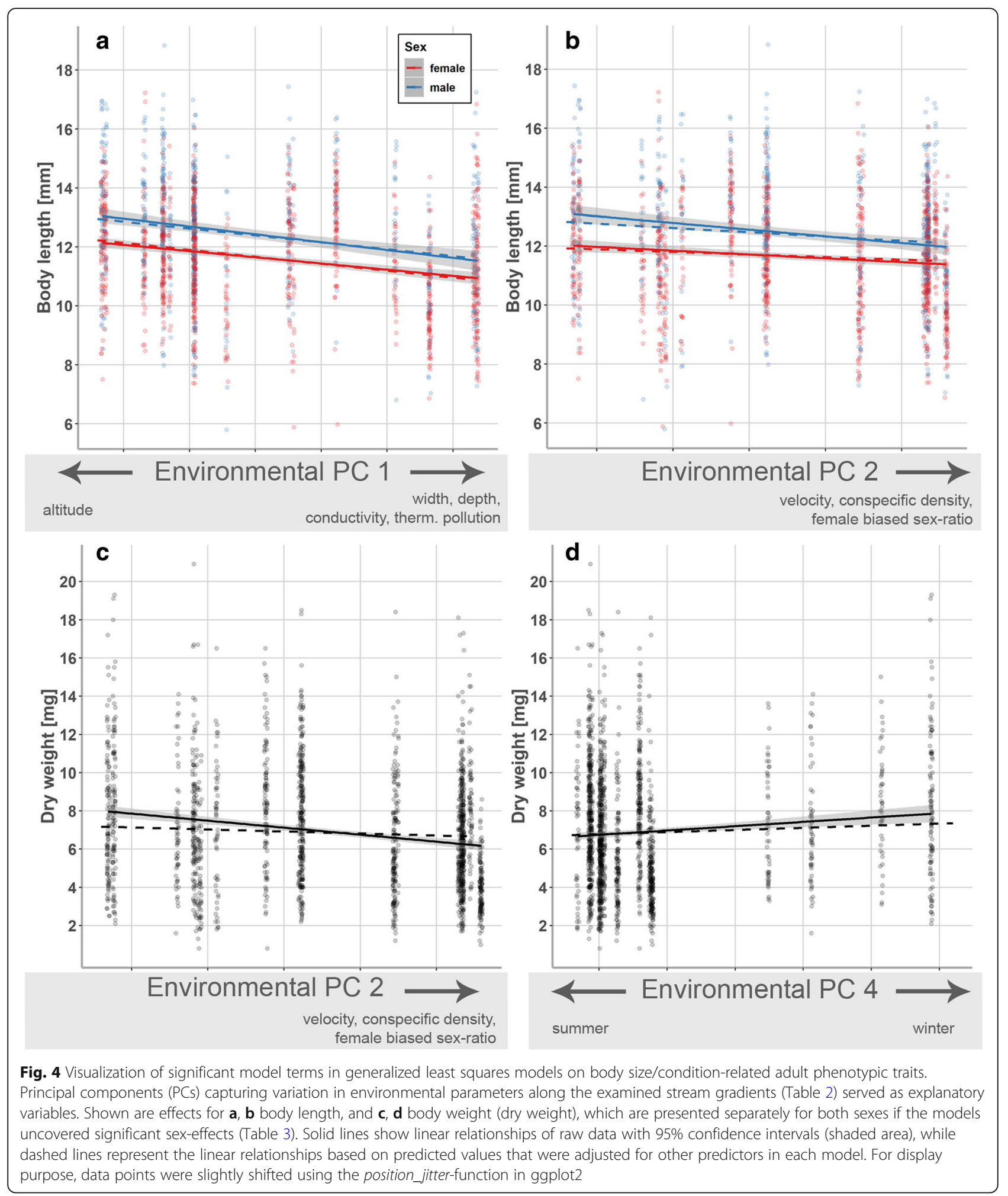

traits affecting ecosystem processes like nutrient and energy flow [123-125]. Nevertheless, both theoretical considerations and empirical evidence suggest that intraspecific phenotypic variation can affect ecosystem processes
[126-128]. For example, divergence in foraging traits of predatory fish species can alter the structure and dynamics of ecological communities by decreasing the mean body size, total biomass, and species richness of 


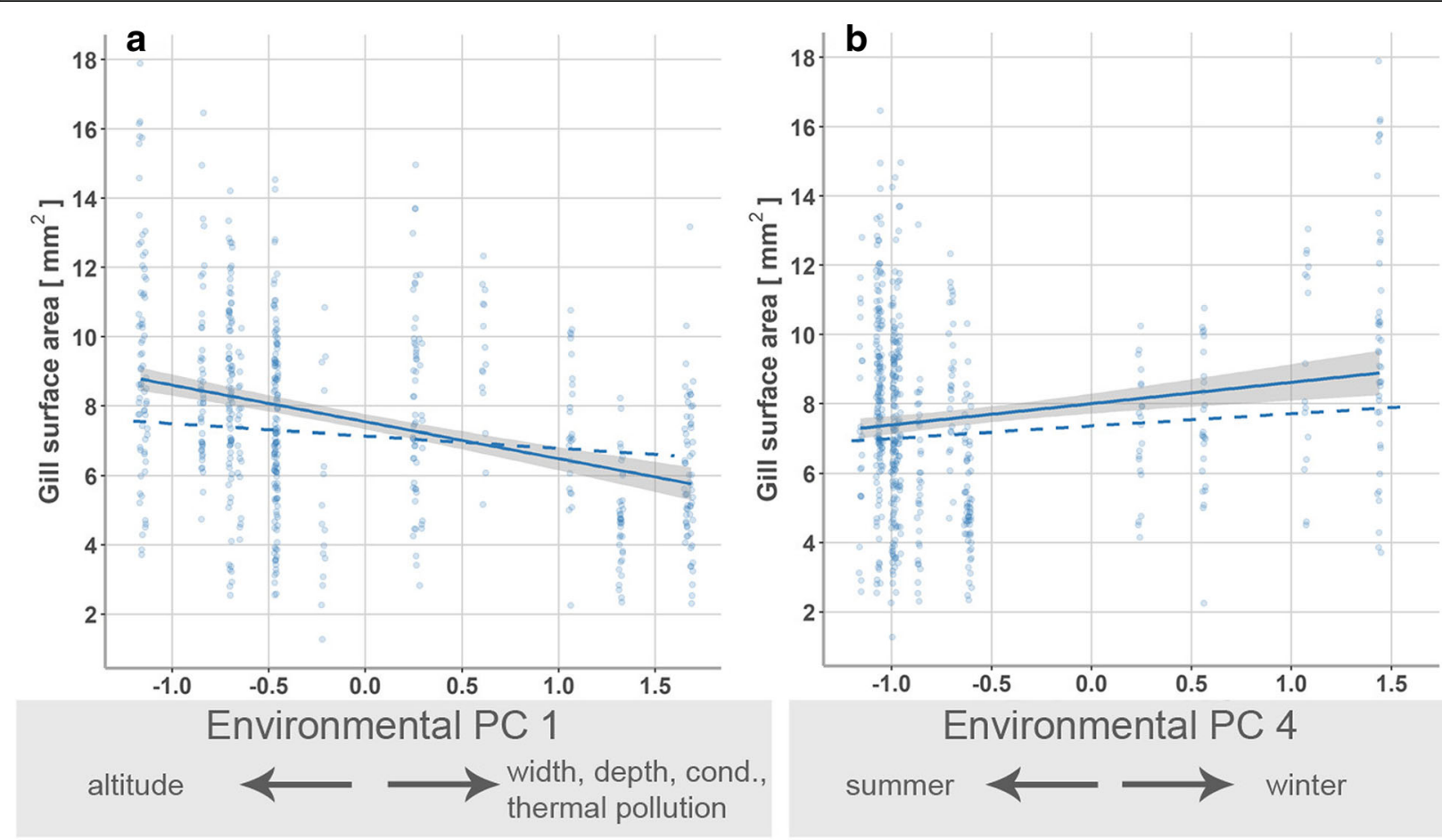

Fig. 5 Visualization of significant model terms in generalized least squares models on gill surface areas. Shown are the relationships between male gill surface areas and $\mathbf{a}$ environmental principal component (PC) 1 and $\mathbf{b}$ PC 4 (Table 3). Solid lines show linear relationships of raw data with 95\% confidence intervals (shaded area), while dashed lines represent the linear relationships based on predicted values that were adjusted for other predictors in the model (e.g., body length). For display purpose, data points were slightly shifted using the position_jitter-function in ggplot2

crustacean zooplankton [129]. The consequences of phenotypic divergence for ecological processes should be particularly strong when the species under consideration acts as a keystone species or ecosystem engineer [130] or when it is simply very abundant [127]. Amphipods are considered to be key components of limnic food webs, as their shredding activity accelerates leaf fragmentation, produces faecal pellets, and transfers nutrients into secondary production, all of which are vital for maintaining diverse aquatic food webs [131-135]. Hence, rapid evolutionary divergence of amphipods along stream gradients is likely to result in multiple feedbacks between evolutionary and ecological processes [136-138]. For example, G. roeselii shows the strongest degree of body size-dependency in leaf litter decomposition rates amongst several species of native and non-native amphipods in the Rhine drainage (see Additional file 1: Figure $S 2$ in ref. [139]). Hence, the strong decline in body size across the stream gradient reported here will have an effect on decomposition rates and food web dynamics. Ecological studies have merely just begun to acknowledge the role of rapid phenotypic divergence in the provisioning of ecosystem services $[128,136,140]$, and our present study identifies invasive amphipods as prime candidates for future studies in this direction. Specifically, future studies could quantify decomposition rates [139] of phenotypically divergent populations to explicitly integrate differences in functional responses as a consequence of the observed trait variation and to understand how they translate into differences in ecosystem functioning [140-142].

\section{Drivers of phenotypic divergence along the examined stream gradients}

The native distribution range of G. roeselii is characterized by its karst topography, with spatio-temporally diverse ecological conditions along stream gradients [143, 144]. Therefore, G. roeselii might have a high potential to inhabit variable environments, either by phenotypic plasticity (see below) or through adaptive evolutionary divergence (local adaptation; see also Additional file 1: Material S1). In support of this idea, a substantial amount of the observed phenotypic trait divergence we found in our dataset could be explained by selection factors that we condensed into principal components. We will base our discussion largely on a priori predictions of how single components of the river gradient should affect trait divergence (Table 1), but acknowledge that additional factors that were not assessed here (e.g., predation pressure $[145,146]$, competition with congeneric species [147]) may have driven parts of the observed divergence. 


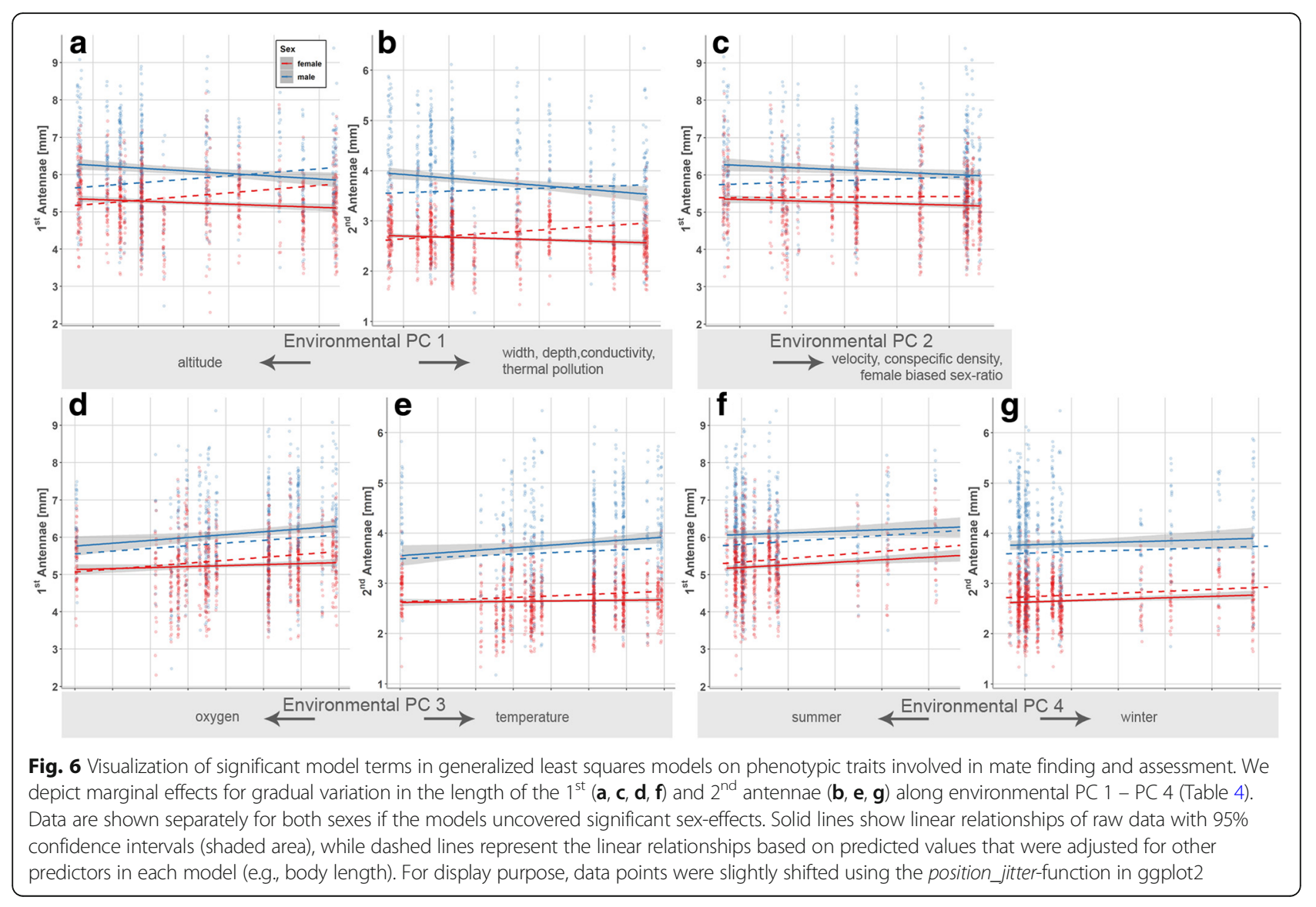

\section{Selection from abiotic factors}

Abiotic factors had strong effects on phenotypic divergence of various traits. For instance, we found larger individuals at upstream sites. In arthropods, larger specimens tend to have an increased ability to withstand environmental fluctuation [47, 48]. Temperature regimes are more variable and winter temperatures colder at higher altitudes, and increased tolerance to low temperatures in large-bodied individuals was empirically confirmed for Gammarus lacustris [50]. Increased body size at higher altitudes appears to be a widespread pattern in arthropods, unless high seasonality leads to a reduced resource availability and ultimately results in smaller body size at higher altitudes [47, 148]. As a leaf shredding species [139], G. roeselii is not resource-limited at upstream sites (i.e., higher altitudes), allowing individuals from those populations to grow to a bigger size.

Counter to our prediction based on the efficiency of oxygen uptake under low oxygen tension [46], we found no response in gill surface area to oxygen conditions; instead we found a pronounced decrease in gill surface areas towards downstream conditions and at sites receiving industrial cooling water. Even though we are lacking quantitative information on pollution loads (other than conductivity as a broad and indirect proxy of total dissolved ions), we argue that increased concentrations of anthropogenic contaminants might explain this pattern ([70]; Table 1). Cooling water often contains additive biocides such as chlorine, corrosion inhibitors, or antifreezers [149]. In support of this interpretation, we found more incidences of intersex at sites that receive cooling water (Additional file 1: Material S4). Biocides are suspected to disturb the hormone balance between androgens and estrogens and facilitate development of both, male and female characteristics at the same time; however, the biochemical pathways that induce intersex are diverse and still remain controversial $[106,150]$. Moreover, contaminants of both natural (e.g., from nitrogenous waste products or soil erosion [109]) and anthropogenic origin (e.g., effluents from wastewater treatment plants and agriculture [151-153]) accumulate towards downstream sites. We argue that smaller gill surface areas are adaptive in that they facilitate a reduced uptake of bioaccumulating contaminants (e.g., heavy metals [109]) or to account for changing concentration of ions in the water (i.e., osmoregulatory purposes [154]).

\section{Selection from biotic factors}

We found systematic co-variation of population demography and densities along the examined river stretches. Specifically, higher population densities were associated 


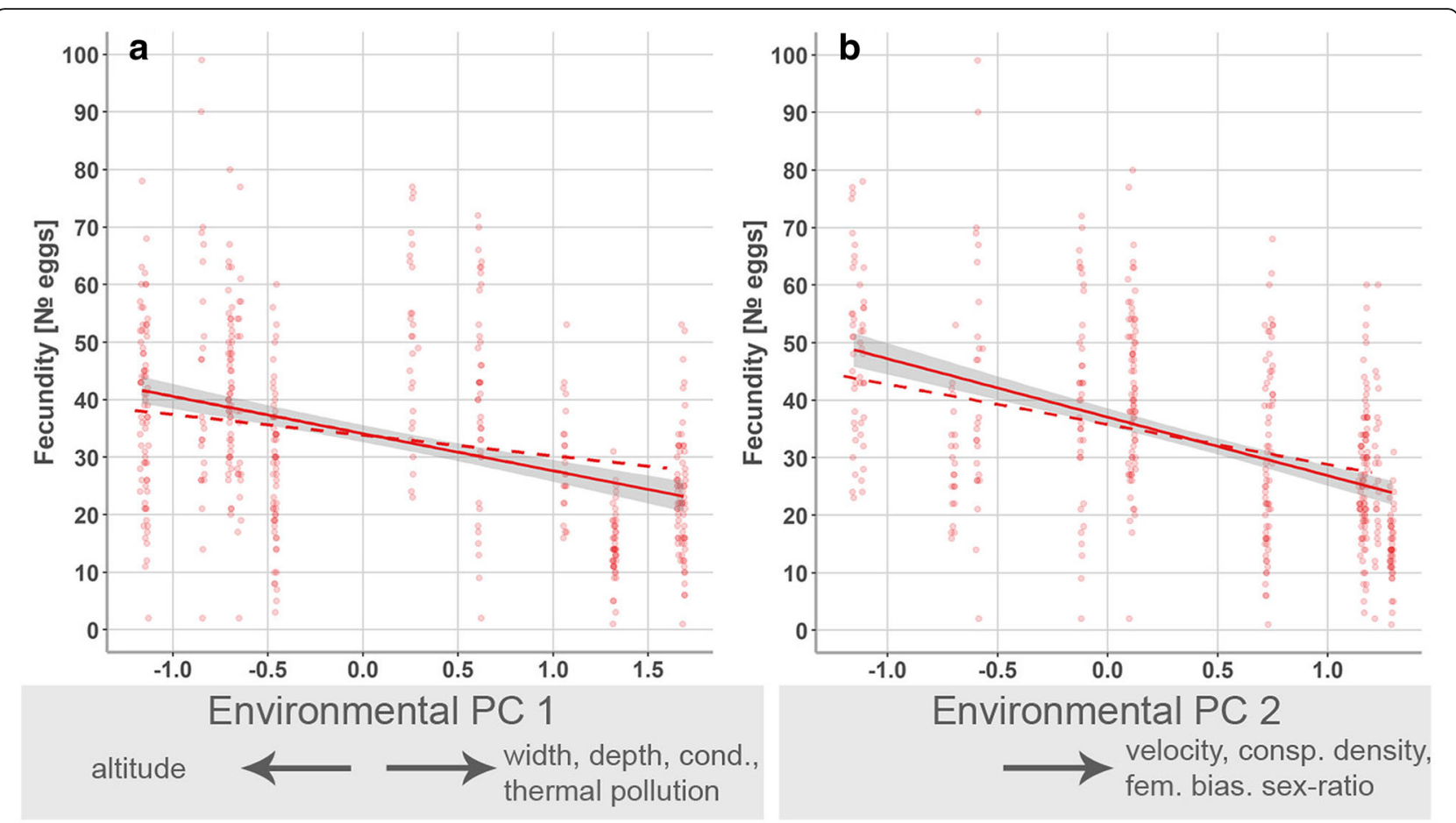

Fig. 7 Visualization of significant model terms in generalized least squares models using offspring-related phenotypic traits as the dependent variable. We depict predicted marginal effects for female fecundity along principal components that contain information of environmental variation along the examined stream gradients [(a) environmental PC 1, (b) environmental PC 2; Table 5]. Solid lines show linear relationships of raw data with 95\% confidence intervals (shaded area), while dashed lines represent the linear relationships based on predicted values that were adjusted for other predictors in each model. For display purpose, data points were slightly shifted using the position_jitter-function in ggplot2

with more female biased sex-ratios. The exact mechanisms underlying this patterns could not be examined in the course of our present study. A likely explanation could be sex-distortion through parasites [155], as parasite transmission probably increases with increasing population densities. For example, presence of the microsporidian Nosema granulosis is associated with an excess of females in G. roeselii broods [156].

Our analyses uncovered divergence of sexually selected male traits towards sites with higher densities and towards female biased sex-ratios. Specifically, the sexual dimorphism in the $1^{\text {st }}$ antennae $[71,112]$ became more pronounced (Fig. 6c). Male amphipods use their antennae to assess the quality of potential mating partners [72]. They bear high costs of mating due to precopulatory mate guarding [157], which should indeed select for pronounced male mate choosiness [158]. Interestingly, mate choosiness in our study species was stronger in males originating from a high-density site compared to males from a low-density site [113]. Based on the aforementioned considerations, we suggest the following scenario: systematic variation of (unrecognized) ecological factors (e.g., predation pressure $[145,146]$ and/or competition with congeneric species [147]) along the examined stream sections drove differences in population densities. Mediated by parasitism [156], this altered population demographics, which in turn altered the fitness landscape for sexually selected traits. Moreover, we predicted body size to be positively sexually selected at high conspecific densities $[59,60]$ (Table 1), but instead found reduced body size in both sexes. This likely reflects elevated resource competition at high population densities translating into reduced somatic growth [159].

Finally, also reproductive traits changed in response to biotic conditions, such as population densities, and we observed a lower fecundity at high conspecific densities and more female biased sex-ratios. A possible adaptive interpretation could be related to the trade-off between offspring size and fecundity [69], where female fecundity is reduced when selection favours bigger offspring $[1,18$, 160]. Increased offspring size can be adaptive in highly competitive environments (i.e., at high population densities [68, 161]). Our interpretation remains speculative, however, as the effect of larger offspring size under higher population densities was marginally nonsignificant (Additional file 1: Figure S2).

\section{Selection at invasion fronts?}

We further found higher size-corrected fecundity at upstream sites. Our a priori predictions for fecundity, 
based on the existing literature on aquatic invertebrates (Table 1), fail to explain this pattern. Therefore, we argue that selective regimes at upstream sites need to be viewed in light of the species' colonisation history. Upstream sites in Central Europe were only recently invaded by G. roeselii (this study). Individuals on the expanding edge of a population (or invasion front) face a unique selective environment. They encounter native competitors (in this case even congeners [94, 101, 162]) and a new set of abiotic selection factors [163]. Selection arising from this condition may tip the scale of another prominent life-history trade-off, namely the trade-off between investment into reproduction and somatic maintenance, which is related to the trade-off between current and future reproduction [82]. Invaders may thus show more investment into reproduction [164] unless there is a strong trade-off between dispersal abilities and fecundity [165].

\section{Outlook and future research}

Phylogeographic studies on amphipods are becoming common practice to study how past geological events affected macroevolutionary processes [166-168]. By contrast, phenotypic divergence within and between taxonomic groups-as reported here on an intraspecific level for G. roeselii-received little attention so far. Uncertainty remains regarding the underlying mechanisms that caused the observed phenotypic variation, and future studies are warranted that address the potential heritability of the traits studied herein and the role of adaptive phenotypic plasticity [87, 169]. Additionally, parts of the observed phenotypic divergence could also arise from non-adaptive plasticity in response to stressful environments [87] (Additional file 1: Material S1). Future studies could provide broad-sense heritability estimates by rearing individuals under commongarden conditions [170], or make an attempt to rear individual broods from known parents to provide narrow-sense heritability estimates $\left(h_{\mathrm{n}}{ }^{2}\right.$, via mid-parent - offspring regressions [171]). To experimentally address some of the newly generated hypotheses, future studies could use the sister genus Hyalella, which is easy to breed under laboratory conditions. Hyalella spp. are routinely used in North America as a model organism for ecotoxicological assays [172] and contemporary evolution to anthropogenic sources of selection (pesticide exposure) has been described [173]. On the other hand, the relative role of plastic responses could be addressed experimentally by assessing the variance of traits, for example, in reciprocal transplant experiments [174, 175]. Finally, genome- and transcriptome-screens could provide insights into the underlying mechanisms of phenotypic divergence, and the widespread occurrence of $G$. roeselii offers several independent populations to test for parallel adaptive divergence. Altogether then, our present study identifies amphipods are promising models to study phenotypic diversification along ecological gradients made up by both natural and human-induced selection factors. Furthermore, their key-role in freshwater ecosystems renders amphipods an excellent system in which to investigate feedbacks between evolutionary and ecological processes.

\section{Additional file}

\begin{abstract}
Additional file 1: Material S1. Additional information on sources of phenotypic divergence. Material S2. Additional information on genetic differentiation in Gammarus roeselii. Material S3. Additional information on life-history characteristics of Gammarus roeselii. Material S4. Additional information on intersexuality. Material S5. Additional information on embryonic developmental stages. Material S6. Information on study sites, additional results and model summaries. Table S1. Environmental conditions for each sampling site. Table S2. PC scores per season and site.

Table S3. Numbers of (a) sex-determined specimens for each sampling site with number of intersex individuals and (b) individuals used for measuring phenotypic traits (male $\hat{\delta}$, female $q$ ). Figure $\mathbf{S} 1$. Relationship of body length to head capsule length. Figure S2. Visualization of the marginally non-significant model term in generalized least squares models using offspring-size as the dependent variable. Table S4. Body length.

Table S5. Dry weight. Table S6. Gill surface area. Table S7. $1^{\text {st }}$ Antennae. Table S8. $2^{\text {nd }}$ Antennae. Table S9. Gnathopod length. Table S10. Fecundity. Table S11. Egg size. Figure S3. Quantile-quantile (QQ) plots of the model residuals. Figure S4. Pictures of sampling sites. Table S12. Location of sampling sites. (DOCX 1830 MB)
\end{abstract}

\section{Abbreviations}

GLS: Generalized least squares model; PC: Principal component

\section{Acknowledgements}

We thank U. Rose, A. Sundermann and P. Haase for rendering support to this project. We further wish to thank M. Oetken for valuable discussions.

\section{Authors' contributions}

$J J$ and AW developed the study idea and established the research protocol. KP and JJ collected samples. KP collected the data. JJ conducted the statistical analyses. JJ and MP discussed the conceptual framework and outline of this manuscript. JJ and MP jointly wrote the article. All authors read and approved the final version of the manuscript.

\section{Availability of data and materials}

The datasets used and analysed for this study are available from the corresponding author upon reasonable request.

\section{Ethics approval}

All animal work in the present study was conducted according to relevant national and international guidelines. The field sampling did not involve endangered or protected species.

Consent for publication

Not applicable.

\section{Competing interests}

The authors declare that they have no competing interests.

\section{Author details}

${ }^{1}$ Department of Aquatic Ecotoxicology, Institute for Ecology, Evolution and Diversity, Goethe University Frankfurt am Main, Frankfurt am Main, Germany. ${ }^{2}$ Department of River Ecology and Conservation, Senckenberg Research Institute and Natural History Museum Frankfurt, Gelnhausen, Germany. ${ }^{3}$ National Museum of Natural History Luxembourg, Luxembourg City, Luxembourg. ${ }^{4}$ College of Animal Science and Technology, Northwest A\&F University, Yangling, People's Republic of China. ${ }^{5}$ Shaanxi Key Laboratory for 
Molecular Biology for Agriculture, Northwest A\&F University, Yangling, People's Republic of China.

\section{Received: 21 December 2018 Accepted: 24 June 2019 Published online: 11 July 2019}

\section{References}

1. Endler JA. Natural selection in the wild: Princeton University press; 1986.

2. Rundle HD, Nagel L, Boughman JW, Schluter D. Natural selection and parallel speciation in sympatric sticklebacks. Science. 2000;287(5451):306-8.

3. Ouyang X, Gao J, Xie M, Liu B, Zhou L, Chen B, Jourdan J, Riesch R, Plath M. Natural and sexual selection drive multivariate phenotypic divergence along climatic gradients in an invasive fish. Sci Rep. 2018:8(1):11164.

4. Andersson MB. Sexual selection: Princeton University press; 1994.

5. Jourdan J, Krause S, Lazar VM, Zimmer C, Sommer-Trembo C, AriasRodriguez L, Klaus S, Riesch R, Plath M. Shared and unique patterns of phenotypic diversification along a stream gradient in two congeneric species. Sci Rep. 2016;6:38971.

6. Riesch $R$, Plath M, Bierbach D. Ecology and evolution along environmental gradients. Curr Zool. 2018;64(2):193-6.

7. Riesch R, Tobler M, Lerp H, Jourdan J, Doumas T, Nosil P, Langerhans RB, Plath M. Extremophile Poeciliidae: multivariate insights into the complexity of speciation along replicated ecological gradients. BMC Evol Biol. 2016;16: $1361-15$.

8. Kawecki TJ, Ebert D. Conceptual issues in local adaptation. Ecol Lett. 2004; 7(12):1225-41.

9. Palo J, O'Hara RB, Laugen AT, Laurila A, Primmer CR, Merilä J. Latitudinal divergence of common frog (Rana temporaria) life history traits by natural selection: evidence from a comparison of molecular and quantitative genetic data. Mol Ecol. 2003;12(7):1963-78.

10. Heibo E, Magnhagen C, Vøllestad LA. Latitudinal variation in life-history traits in Eurasian perch. Ecology. 2005;86(12):3377-86.

11. Watt C, Mitchell S, Salewski V. Bergmann's rule; a concept cluster? Oikos. 2010;119(1):89-100.

12. Hodkinson ID. Terrestrial insects along elevation gradients: species and community responses to altitude. Biol Rev. 2005;80(3):489-513.

13. O'Gorman EJ, Ólafsson ÓP, Demars BO, Friberg N, Guðbergsson G, Hannesdóttir ER, Jackson MC, Johansson LS, McLaughlin ÓB, Ólafsson JS. Temperature effects on fish production across a natural thermal gradient. Glob Chang Biol. 2016;22(9):3206-20.

14. Gomez-Mestre I, Tejedo M. Contrasting patterns of quantitative and neutral genetic variation in locally adapted populations of the natterjack toad, Bufo calamita. Evolution. 2004;58(10):2343-52.

15. Laverty G, Skadhauge E. Hypersaline Environments. In: Riesch R, Tobler M, Plath $M$, editors. Extremophile fishes. Ecology, evolution, and physiology of Teleosts in extreme environments. Heidelberg: Springer; 2015. p. 85-106.

16. Hangartner S, Laurila A, Räsänen K. Adaptive divergence of the moor frog (Rana arvalis) along an acidification gradient. BMC Evol Biol. 2011;11(366): 366.

17. Nelson JA. Pickled Fish Anyone? Extremophile fishes. Ecology, evolution, and physiology of Teleosts in extreme environments. Heidelberg: Springer; 2015. p. 193-215.

18. Reznick $D$, Endler JA. The impact of predation on life history evolution in Trinidadian guppies (Poecilia reticulata). Evolution. 1982:36(1):160-77.

19. Bolnick DI. Can intraspecific competition drive disruptive selection? An experimental test in natural populations of sticklebacks. Evolution. 2004; 58(3):608-18.

20. Connell JH. The influence of interspecific competition and other factors on the distribution of the barnacle Chthamalus stellatus. Ecology. 1961;42(4): 710-23.

21. Stubbington R, Chadd R, Cid N, Csabai Z, Miliša M, Morais M, Munné A, Pařil $P$, Pešić $V$, Tziortzis I. Biomonitoring of intermittent rivers and ephemeral streams in Europe: current practice and priorities to enhance ecological status assessments. Sci Total Environ. 2018;618:1096-113.

22. Siepielski AM, Morrissey MB, Buoro M, Carlson SM, Caruso CM, Clegg SM, Coulson T, DiBattista J, Gotanda KM, Francis CD. Precipitation drives global variation in natural selection. Science. 2017;355(6328):959-62.

23. Allan JD. Stream ecology. London: Chapman \& Hall; 1995.

24. Wetzel RG. Limnology: lake and river ecosystems. 3rd ed. San Diego: Academic Press; 2001.
25. Vannote RL, Minshall GW, Cummins KW, Sedell JR, Cushing CE. The river continuum concept. Can J Fish Aquat Sci. 1980;37(1):130-7.

26. Zenker A, Cicero MR, Prestinaci F, Bottoni P, Carere M. Bioaccumulation and biomagnification potential of pharmaceuticals with a focus to the aquatic environment. J Environ Manag. 2014;133:378-87.

27. Brown $C D$, Van Beinum W. Pesticide transport via sub-surface drains in Europe. Environ Pollut. 2009;157(12):3314-24.

28. Wagner M, Scherer C, Alvarez-Muñoz D, Brennholt N, Bourrain X, Buchinger S, Fries E, Grosbois C, Klasmeier J, Marti T. Microplastics in freshwater ecosystems: what we know and what we need to know. Environ Sci Eur. 2014;26(1):12.

29. Kløve B, Ala-Aho P, Bertrand G, Boukalova Z, Ertürk A, Goldscheider N, IImonen J, Karakaya N, Kupfersberger H, Kvoerner J. Groundwater dependent ecosystems. Part I: Hydroecological status and trends. Environ Sci Pol. 2011; 14(7):770-81.

30. Moore RD, Spittlehouse D, Story A. Riparian microclimate and stream temperature response to forest harvesting: a review. J Am Water Resour Assoc. 2005;41:813-34.

31. Molini A, Katul GG, Porporato A. Maximum discharge from snowmelt in a changing climate. Geophys Res Lett. 2011;1-5.

32. Marxsen J, Zoppini A, Wilczek S. Microbial communities in streambed sediments recovering from desiccation. FEMS Microbiol Ecol. 2010;71(3): 374-86.

33. Mariotti A, Struglia MV, Zeng N, Lau K. The hydrological cycle in the Mediterranean region and implications for the water budget of the Mediterranean Sea. J Clim. 2002;15(13):1674-90.

34. IPCC. Climate change 2014: synthesis report. Contribution of Working Groups I, II and III to the fifth assessment report of the Intergovernmental Panel on Climate Change. In: Pachauri RK, Allen MR, Barros VR, Broome J, Cramer W, Christ R, Church JA, Clarke L, Dahe Q, Dasgupta P, editors. 2014. http://www.ipcc.ch/report/ar5/syr/ (13072017)

35. Vidon $P G$, Hill AR. Landscape controls on the hydrology of stream riparian zones. J Hydrol. 2004;292(1-4):210-28.

36. Jourdan J, O'Hara RB, Bottarin R, Huttunen K-L, Kuemmerlen M, Monteith D, Muotka T, Ozolinš D, Paavola R, Pilotto F, et al. Effects of changing climate on European stream invertebrate communities: a long-term data analysis. Sci Total Environ. 2018;621:588-99.

37. Allan JD. Landscapes and riverscapes: the influence of land use on stream ecosystems. Annu Rev Ecol Evol Syst. 2004;35:257-84.

38. Woodward G, Perkins DM, Brown LE. Climate change and freshwater ecosystems: impacts across multiple levels of organization. Philos Trans $R$ Soc Lond B Biol Sci. 2010;365(1549):2093.

39. Berger $E$, Haase P, Kuemmerlen M, Leps M, Schäfer RB, Sundermann A. Water quality variables and pollution sources shaping stream macroinvertebrate communities. Sci Total Environ. 2017:587:1-10.

40. Endler JA. Multiple-trait coevolution and environmental gradients in guppies. Trends Ecol Evol. 1995;10(1):22-9.

41. Jażdżewski K. Range extensions of some gammaridean species in European inland waters caused by human activity. Crustaceana Suppl. 1980:6:84-107.

42. Marchant R, Hynes H. The distribution and production of Gammarus pseudolimnaeus (Crustacea: Amphipoda) along a reach of the Credit River, Ontario. Freshw Biol. 1981;11(2):169-82.

43. Dangles O, Gessner MO, Guerold F, Chauvet E. Impacts of stream acidification on litter breakdown: implications for assessing ecosystem functioning. J Appl Ecol. 2004;41 (2):365-78.

44. Franssen NR, Harris J, Clark SR, Schaefer JF, Stewart LK. Shared and unique morphological responses of stream fishes to anthropogenic habitat alteration. Proc R Soc B Biol Sci. 2013;280(1752):20122715.

45. Haas TC, Heins DC, Blum MJ. Predictors of body shape among populations of a stream fish (Cyprinella venusta, Cypriniformes: Cyprinidae). Biol J Linn Soc. 2015;115(4):842-58.

46. Dodds G, Hisaw FL. Ecological studies of aquatic insects: size of respiratory organs in relation to environmental conditions. Ecology. 1924;5(3):262-71.

47. Chown SL, Gaston KJ. Body size variation in insects: a macroecological perspective. Biol Rev. 2010;85(1):139-69

48. Horne CR, Hirst A, Atkinson D. Temperature-size responses match latitudinal-size clines in arthropods, revealing critical differences between aquatic and terrestrial species. Ecol Lett. 2015;18(4):327-35.

49. de March B. The effects of constant and variable temperatures on the size, growth, and reproduction of the freshwater amphipod Hyalella azteca (Saussure). Can J Zool. 1978;56(8):1801-6. 
50. Wilhelm F, Schindler D. Reproductive strategies of Gammarus lacustris (Crustacea: Amphipoda) along an elevation gradient. Funct Ecol. 2000;14(4): 413-22.

51. Blanckenhorn WU. Different growth responses to temperature and resource limitation in three fly species with similar life histories. Evol Ecol. 1999;13(4):395

52. Beketov MA, Liess M. Predation risk perception and food scarcity induce alterations of life-cycle traits of the mosquito Culex pipiens. Ecol Entomol. 2007:32(4):405-10.

53. Credland PF, Dick KM, Wright AW. Relationships between larval density, adult size and egg production in the cowpea seed beetle, Callosobruchus maculatus. Ecol Entomol. 1986;11(1):41-50.

54. Wellborn GA. Trade-off between competitive ability and antipredator adaptation in a freshwater amphipod species complex. Ecology. 2002;83(1): 129-36.

55. Gross MY, Maycock DS, Thorndyke MC, Morritt D, Crane M. Abnormalities in sexual development of the amphipod Gammarus pulex (L.) found below sewage treatment works. Environ Toxicol Chem. 2001;20(8):1792-7.

56. Jourdan J, Baier J, Riesch R, Klimpel S, Streit B, Müller R, Plath M. Adaptive growth reduction in response to fish kairomones allows mosquito larvae (Culex pipiens) to reduce predation risk. Aquat Sci. 2016:78(2):303-14

57. Wellborn GA. Size-biased predation and prey life histories: a comparative study of freshwater amphipod populations. Ecology. 1994;75:2104-17.

58. Gliwicz ZM, Boavida MJ. Clutch size and body size at first reproduction in Daphnia pulicaria at different levels of food and predation. J Plankton Res. 1996;18(6):863-80.

59. Bollache L, Cézilly F. Sexual selection on male body size and assortative pairing in Gammarus pulex (Crustacea: Amphipoda): field surveys and laboratory experiments. J Zool. 2004;264(2):135-41.

60. Bertin A, Cézilly F. Sexual selection, antennae length and the mating advantage of large males in Asellus aquaticus. J Evol Biol. 2003;16(3):491500.

61. Glazier DS. Is fatter fitter? Body storage and reproduction in ten populations of the freshwater amphipod Gammarus minus. Oecologia. 2000;122(3):33545

62. Lagrue C, Besson AA, Lecerf A. Interspecific differences in antipredator strategies determine the strength of non-consumptive predator effects on stream detritivores. Oikos. 2015:124(12):1589-96.

63. Benard MF. Predator-induced phenotypic plasticity in organisms with complex life histories. Annu Rev Ecol Syst. 2004;35:651-73.

64. Tolba M, Holdich D. The effect of water quality on the size and fecundity of Asellus aquaticus (Crustacea: isopoda). Aquat Toxicol. 1981;1(2):101-12.

65. Ford AT, Fernandes TF, Rider SA, Read PA, Robinson CD, Davies IM. Reproduction in the amphipod, Echinogammarus marinus: a comparison between normal and intersex specimens. J Mar Biol Assoc U K. 2003:83(5): 937-40.

66. Sheader M. Factors influencing egg size in the gammarid amphipod Gammarus insensibilis. Mar Biol. 1996;124(4):519-26.

67. Pöckl M. Reproductive potential and lifetime potential fecundity of the freshwater amphipods Gammarus fossarum and G. roeseli in Austrian streams and rivers. Freshw Biol. 1993;30(1):73-91.

68. Wellborn GA, Cothran R, Bartholf S. Life history and allozyme diversification in regional ecomorphs of the Hyalella azteca (Crustacea: Amphipoda) species complex. Biol J Linn Soc. 2005;84(2):161-75.

69. Glazier DS. Smaller amphipod mothers show stronger trade-offs between offspring size and number. Ecol Lett. 2000;3(2):142-9.

70. Roast S, Jones M. Morphometrics and gill function in Gammarus duebeni (Peracarida: Amphipoda) inhabiting a sewage treatment works. Mar Ecol Prog Ser. 2003;260:189-94.

71. Nahavandi N, Plath M, Tiedemann R, Mirzajani AR. Sexual and natural selection on morphological traits in a marine amphipod, Pontogammarus maeoticus (Sowinsky, 1894). Mar Biol Res. 2011;7(2):135-46.

72. Dick JT, Elwood RW. Effects of natural variation in sex ratio and habitat structure on mate-guarding decisions in amphipods (Crustacea). Behaviour. 1996;133(13):985-96.

73. Brown R, Conradi M, Depledge M. Long-term exposure to 4-nonylphenol affects sexual differentiation and growth of the amphipod Corophium volutator (\# Pallas, 1766). Sci Total Environ. 1999:233(1-3):77-88.

74. Watts MM, Pascoe D, Carroll K. Population responses of the freshwater amphipod Gammarus pulex (L.) to an environmental estrogen, $17 \mathrm{a}-$ ethinylestradiol. Environ Toxicol Chem. 2002;21(2):445-50.
75. Berglund A. Many mates make male pipefish choosy. Behaviour. 1995; 132(3):213-8

76. Villarreal AE, Godin JGJ, Bertram SM. Influence of the operational sex ratio on mutual mate choice in the Jamaican field cricket (Gryllus assimilis): testing the predictions of the switch point theorem. Ethology. 2018;124(11): 816-28.

77. Ward PI, Porter AH. The relative roles of habitat structure and male-male competition in the mating sytem of Gammarus pulex (Crustacea; Amphipoda): a simulation study. Anim Behav. 1993;45(1):119-33.

78. Grether GF, Hudon J, Millie DF. Carotenoid limitation of sexual coloration along an environmental gradient in guppies. Proc R Soc Lond B Biol Sci. 1999;266(1426):1317-22.

79. Lindholm AK, Head M, Brooks R, Rollins L, Ingleby F, Zajitschek SR. Causes of male sexual trait divergence in introduced populations of guppies. J Evol Biol. 2014;27(2):437-48.

80. Piggott JJ, Townsend CR, Matthaei CD. Reconceptualizing synergism and antagonism among multiple stressors. Ecol Evol. 2015;5(7):1538-47.

81. Losos JB, Schoener TW, Langerhans RB, Spiller DA. Rapid temporal reversal in predator-driven natural selection. Science. 2006;314(5802):1111.

82. Stearns SC. Trade-offs in life-history evolution. Funct Ecol. 1989;3(3):259-68.

83. Wilbur HM, Tinkle DW, Collins JP. Environmental certainty, trophic level, and resource availability in life history evolution. Am Nat. 1974;108(964):805-17.

84. Borowsky B. The use of the males' gnathopods during precopulation in some gammaridean amphipods. Crustaceana. 1984;47(3):245-50.

85. Stockwell CA, Hendry AP, Kinnison MT. Contemporary evolution meets conservation biology. Trends Ecol Evol. 2003;18(2):94-101.

86. Reznick DN, Losos J, Travis J. From low to high gear: there has been a paradigm shift in our understanding of evolution. Ecol Lett. 2019;22(2):23344.

87. Ghalambor CK, McKay JK, Carroll SP, Reznick DN. Adaptive versus nonadaptive phenotypic plasticity and the potential for contemporary adaptation in new environments. Funct Ecol. 2007:21(3):394-407.

88. Jourdan J, Miesen FW, Zimmer C, Gasch K, Herder F, Schleucher E, Plath M, Bierbach D. On the natural history of an introduced population of guppies (Poecilia reticulata Peters, 1859) in Germany. Bioinvasions Rec. 2014;3(3):17584.

89. Lukas JA, Jourdan J, Kalinkat G, Emde S, Miesen FW, Jüngling H, Cocchiararo $B$, Bierbach D. On the occurrence of three non-native cichlid species including the first record of a feral population of Pelmatolapia (Tilapia) mariae (Boulenger, 1899) in Europe. R Soc Open Sci. 2017:4(6):170160.

90. Gaudard A, Weber C, Alexander TJ, Hunziker S, Schmid M. Impacts of using lakes and rivers for extraction and disposal of heat. Wiley Interdiscip Rev Water. 2018;5:e1295.

91. Bergman C. Über die Verhältnisse der Wärmeökonomie der Thiere zu ihrer Grösse. Göttinger Studien. 1847;3:595-708.

92. Merilä J, Hendry AP. Climate change, adaptation, and phenotypic plasticity: the problem and the evidence. Evol Appl. 2014;7(1):1-14.

93. Josens G, de Bij VA, Usseglio-Polatera P, Cammaerts R, Cherot F, Grisez F, Verboonen P, Bossche J-PV. Native and exotic Amphipoda and other Peracarida in the river Meuse: new assemblages emerge from a fast changing fauna. Hydrobiologia. 2005;542:203-20.

94. Meijering MP. Lack of oxygen and low pH as limiting factors for Gammarus in hessian brooks and rivers. Hydrobiologia. 1991:223(1):159-69.

95. Pöckl M, Webb BW, Sutcliffe DW. Life history and reproductive capacity of Gammarus fossarum and G. roeseli (Crustacea: Amphipoda) under naturally fluctuating water temperatures: a simulation study. Freshw Biol. 2003;48(1): 53-66.

96. Van Riel M, Van der Velde G, Rajagopal S, Marguillier S, Dehairs F. Bij de Vaate a: trophic relationships in the Rhine food web during invasion and after establishment of the Ponto-Caspian invader Dikerogammarus villosus. Hydrobiologia. 2006:565:39-58.

97. Bij de Vaate A, Jazdzewski K, Ketelaars HA, Gollasch S, Van der Velde G. Geographical patterns in range extension of Ponto-Caspian macroinvertebrate species in Europe. Can J Fish Aquat Sci. 2002;59(7):1159-74.

98. Rewicz T, Wattier R, Grabowski M, Rigaud T, Bącela-Spychalska K. Out of the Black Sea: Phylogeography of the invasive killer shrimp Dikerogammarus villosus across Europe. PLoS One. 2015;10(2):e0118121.

99. Mirtl M, Borer E, Burns E, Djukic I, Forsius M, Haubold H, Hugo W, Jourdan J, Lindenmayer D, WH MD, et al. Genesis, goals and achievements of LongTerm Ecological Research at the global scale: A critical review of ILTER and future directions. Sci Total Environ. 2018;626:1439-62. 
100. Mykra H, Ruokonen T, Muotka T. The effect of sample duration on the efficiency of kick-sampling in two streams with contrasting substratum heterogeneity. Int Ver Theor Angew Limnol Verh. 2006;29(3):351-5.

101. Chen W, Bierbach D, Plath M, Streit B, Klaus S. Distribution of amphipod communities in the middle to upper Rhine and five of its tributaries. Bioinvasions Rec. 2012;1(4):263-71.

102. Eggers TO, Martens A. Bestimmungsschlüssel der Süßwasser-Amphipoda (Crustacea) Deutschlands: Erik Mauch Verlag; 2001.

103. Eiseler B. Taxonomie für die Praxis. BestimmungshilfenMakrozoobenthos (1) LANUV-Arbeitsblatt 14. In: Landesamt für Natur Umwelt und Verbraucherschutz Nordrhein-Westfalen (LANUV NRW), Recklinghausen; 2010.

104. Kaiser HF. The varimax criterion for analytic rotation in factor analysis. Psychometrika. 1958;23(3):187-200.

105. Sutcliffe DW. Reproduction in Gammarus (Crustacea, Amphipoda): basic processes. In: Freshwater Forum; 2010

106. Ford AT. Intersexuality in Crustacea: an environmental issue? Aquat Toxicol. 2012;108:125-9.

107. Derry AM, Kestrup ÅM, Hendry AP. Possible influences of plasticity and genetic/maternal effects on species coexistence: native Gammarus fasciatus facing exotic amphipods. Funct Ecol. 2013;27(5):1212-23.

108. Steele DH, Steele VJ. The biology of Gammarus (Crustacea, Amphipoda) in the northwestern Atlantic. I. Gammarus duebeni Lillj. Can J Zool. 1969;47(2): 235-44.

109. Henry RP, Lucu C, Onken H, Weihrauch D. Multiple functions of the crustacean gill: osmotic/ionic regulation, acid-base balance, ammonia excretion, and bioaccumulation of toxic metals. Front Physiol. 2012;3:431.

110. Rainbow PS. Physiology, physicochemistry and metal uptake-a crustacean perspective. Mar Pollut Bull. 1995;31(1-3):55-9.

111. Shires R, Lane N, Inman C, Lockwood A. Structural changes in the gill cells of Gammarus duebeni (Crustacea, Amphipoda) under osmotic stress; with notes on microtubules in association with the septate junctions. Tissue Cell. 1994;26(5):767-78.

112. Conlan KE. Precopulatory mating behavior and sexual dimorphism in the amphipod Crustacea. Hydrobiologia. 1991;223(1):255-82.

113. Lipkowski K, Plath M, Klaus S, Sommer-Trembo C. Population density affects morphology and male mate choosiness in the mate-guarding amphipod Gammarus roeselii (Crustacea: Amphipoda). Biol J Linn Soc. 2019;126(4):899-911.

114. McCahon C, Pascoe D. Increased sensitivity to cadmium of the freshwater amphipod Gammarus pulex (L.) during the reproductive period. Aquat Toxicol. 1988;13(3):183-93.

115. Pinheiro J, Bates D, DebRoy S, Sarkar D: R Core Team (2018) nlme: linear and nonlinear mixed effects models. R package version 3.1-137. 2014. Available at http://CRAN.R-project.org/package=nlme.

116. Littell RC, Pendergast J, Natarajan R. Modelling covariance structure in the analysis of repeated measures data. Stat Med. 2000;19(13):1793-819.

117. Fox J, Weisberg S, Adler D, Bates D, Baud-Bovy G, Ellison S, Firth D, Friendly M, Gorjanc G, Graves S. Package 'car'. Vienna: R Foundation for Statistical Computing; 2018

118. Lüdecke D. ggeffects: tidy data frames of marginal effects from regression models. J Open Source Softw. 2018;3:772.

119. R Development Core Team. R: A language and environment for statistical computing. Vienna: R Foundation for Statistical Computing 2018. ISBN 3-900051-07-0. URL http://www.R-project.org

120. Bowler DE, Hof C, Haase P, Kröncke I, Schweiger O, Adrian R, Baert L, Bauer H-G, Blick T, Brooker RW. Cross-realm assessment of climate change impacts on species' abundance trends. Nat Ecol Evol. 2017;1: 0067.

121. Domisch S, Araújo MB, Bonada N, Pauls SU, Jähnig SC, Haase P. Modelling distribution in European stream macroinvertebrates under future climates. Glob Chang Biol. 2013;19(3):752-62.

122. Gaston K, Blackburn T. Pattern and process in macroecology. Oxford: Blackwell Science; 2008.

123. Dolédec S, Statzner B, Bournard M. Species traits for future biomonitoring across ecoregions: patterns along a human-impacted river. Freshw Biol. 1999;42(4):737-58.

124. Schmidt-Kloiber A, Hering D. www.freshwaterecology.info - an online too that unifies, standardises and codifies more than 20,000 European freshwater organisms and their ecological preferences. Ecol Indic. 2015;53: 271-82.
125. de Bello F, Lavorel S, Díaz S, Harrington R, Cornelissen JH, Bardgett RD, Berg MP, Cipriotti P, Feld CK, Hering D. Towards an assessment of multiple ecosystem processes and services via functional traits. Biodivers Conserv. 2010;19(10):2873-93.

126. Bassar RD, Marshall MC, López-Sepulcre A, Zandonà E, Auer SK, Travis J, Pringle CM, Flecker AS, Thomas SA, Fraser DF. Local adaptation in Trinidadian guppies alters ecosystem processes. Proc Natl Acad Sci. 2010;107(8):3616-21.

127. Hendry AP, Kinnison MT, Heino M, Day T, Smith TB, Fitt G, Bergstrom CT, Oakeshott J, Jørgensen PS, Zalucki MP. Evolutionary principles and their practical application. Evol Appl. 2011;4(2):159-83.

128. Bolnick DI, Amarasekare P, Araújo MS, Bürger R, Levine JM, Novak M, Rudolf VH, Schreiber SJ, Urban MC, Vasseur DA. Why intraspecific trait variation matters in community ecology. Trends Ecol Evol. 2011;26(4):183-92.

129. Palkovacs EP, Post DM. Experimental evidence that phenotypic divergence in predators drives community divergence in prey. Ecology. 2009;90(2):300-5.

130. Jones CG, Lawton JH, Shachak M. Organisms as ecosystem engineers. Oikos. 1994;69:373-86

131. Petersen RC, Cummins KW. Leaf processing in a woodland stream. Freshw Biol. 1974;4(4):343-68.

132. Dangles O, Malmqvist B. Species richness-decomposition relationships depend on species dominance. Ecol Lett. 2004;7(5):395-402.

133. Wallace JB, Eggert SL, Meyer JL, Webster JR. Multiple trophic levels of a forest stream linked to terrestrial litter inputs. Science. 1997;277(5322):102-4.

134. Navel S, Mermillod Blondion F, Montuelle B, Chauvet E, Simon L, Piscart C, Marmonier P. Interactions between fauna and sediment control the breakdown of plant matter in river sediments. Freshw Biol. 2010;55(4):753-66.

135. Graça MAS. The role of invertebrates on leaf litter decomposition in streams-a review. Int Rev Hydrobiol. 2001;86(4-5):383-93.

136. Rudman SM, Kreitzman M, Chan KM, Schluter D. Evosystem services: rapid evolution and the provision of ecosystem services. Trends Ecol Evol. 2017; 32(6):403-15.

137. Hendry AP, Kinnison MT. Perspective: the pace of modern life: measuring rates of contemporary microevolution. Evolution. 1999:53(6):1637-53.

138. Thompson JN. Rapid evolution as an ecological process. Trends Ecol Evol. 1998;13(8):329-32.

139. Jourdan J, Westerwald B, Kiechle A, Chen W, Streit B, Klaus S, Oetken M, Plath M. Pronounced species turnover, but no functional equivalence in leaf consumption of invasive amphipods in the river Rhine. Biol Invasions. 2016; 18(3):763-74.

140. Des Roches S, Post DM, Turley NE, Bailey JK, Hendry AP, Kinnison MT, Schweitzer JA, Palkovacs EP. The ecological importance of intraspecific variation. Nat Ecol Evol. 2018;2(1):57.

141. Rota T, Jabiol J, Chauvet E, Lecerf A. Phenotypic determinants of interindividual variability of litter consumption rate in a detritivore population. Oikos. 2018;127(11):1670-8.

142. Raffard A, Lecerf A, Cote J, Buoro M, Lassus R, Cucherousset J. The functional syndrome: linking individual trait variability to ecosystem functioning. Proc R Soc B Biol Sci. 2017:284(1868):20171893.

143. Grabowski M, Mamos T, Bącela-Spychalska K, Rewicz T, Wattier RA. Neogene paleogeography provides context for understanding the origin and spatial distribution of cryptic diversity in a widespread Balkan freshwater amphipod. PeerJ. 2017:5:e3016.

144. Mamos T, Wattier R, Burzyński A, Grabowski M. The legacy of a vanished sea: a high level of diversification within a European freshwater amphipod species complex driven by 15 my of Paratethys regression. Mol Ecol. 2016; 25(3):795-810.

145. Nelson WG. Experimental studies of selective predation on ampibpods: consequences for amphipod distribution and abundance. J Exp Mar Biol Ecol. 1979:38(3):225-45.

146. MacNeil C, Platvoet D. The predatory impact of the freshwater invader Dikerogammarus villosus on native Gammarus pulex (Crustacea: Amphipoda); influences of differential microdistribution and food resources. J Zool. 2005; 267(1):31-8.

147. De Gelder S, Van der Velde G, Platvoet D, Leung N, Dorenbosch M, Hendriks $H$, Leuven R. Competition for shelter sites: testing a possible mechanism for gammarid species displacements. Basic Appl Ecol. 2016;17(5):455-62.

148. Chown SL, Klok CJ. Altitudinal body size clines: latitudinal effects associated with changing seasonality. Ecography. 2003;26(4):445-55.

149. Langford T. Ecological effects of thermal discharges: Springer Science \& Business Media; 1990. 
150. Grilo TF, Rosa R. Intersexuality in aquatic invertebrates: prevalence and causes. Sci Total Environ. 2017;592:714-28.

151. Kuster M, de Alda MJL, Hernando MD, Petrovic M, Martín-Alonso J, Barceló D. Analysis and occurrence of pharmaceuticals, estrogens, progestogens and polar pesticides in sewage treatment plant effluents, river water and drinking water in the Llobregat river basin (Barcelona, Spain). J Hydrol. 2008;358(1-2):112-23.

152. Carballa M, Omil F, Lema JM, Llompart M, García-Jares C, Rodríguez I, Gomez M, Ternes T. Behavior of pharmaceuticals, cosmetics and hormones in a sewage treatment plant. Water Res. 2004;38(12):2918-26.

153. Foley JA, DeFries R, Asner GP, Barford C, Bonan G, Carpenter SR, Chapin FS, Coe MT, Daily GC, Gibbs HK. Global consequences of land use. Science. 2005;309(5734):570-4.

154. Moore P, Taylor A. Gill area relationships in an ecological series of gammaridean amphipods (Crustacea). J Exp Mar Biol Ecol. 1984;74(2): 179-86.

155. Grabner DS, Weigand AM, Leese F, Winking C, Hering D, Tollrian R, Sures B. Invaders, natives and their enemies: distribution patterns of amphipods and their microsporidian parasites in the Ruhr Metropolis, Germany. Parasit Vectors. 2015;8(1):419.

156. Haine ER, Motreuil S, Rigaud T. Infection by a vertically-transmitted microsporidian parasite is associated with a female-biased sex ratio and survival advantage in the amphipod Gammarus roeseli. Parasitology. 2007;134(10):1363-7.

157. Plaistow SJ, Bollache L, Cézilly F. Energetically costly precopulatory mate guarding in the amphipod Gammarus pulex: causes and consequences. Anim Behav. 2003;65(4):683-91.

158. Edward DA, Chapman T. The evolution and significance of male mate choice. Trends Ecol Evol. 2011;26(12):647-54.

159. White EP, Ernest SM, Kerkhoff AJ, Enquist BJ. Relationships between body size and abundance in ecology. Trends Ecol Evol. 2007;22(6):323-30.

160. Riesch R, Plath M, Schlupp I, Tobler M, Brian Langerhans R. Colonisation of toxic environments drives predictable life-history evolution in livebearing fishes (Poeciliidae). Ecol Lett. 2014;17(1):65-71.

161. Leips J, Richardson JM, Rodd FH, Travis J. Adaptive maternal adjustments of offspring size in response to conspecific density in two populations of the least killifish, Heterandria formosa. Evolution. 2009;63(5):1341-7.

162. Altermatt F, Alther R, Mächler E. Spatial patterns of genetic diversity, community composition and occurrence of native and non-native amphipods in naturally replicated tributary streams. BMC Ecol. 2016;16:23.

163. Sakai AK, Allendorf FW, Holt JS, Lodge DM, Molofsky J, With KA, Baughman S, Cabin RJ, Cohen JE, Ellstrand NC, et al. The population biology of invasive species. Annu Rev Ecol Syst. 2001;32(1):305-32.

164. Burton OJ, Phillips BL, Travis JM. Trade-offs and the evolution of life-histories during range expansion. Ecol Lett. 2010;13(10):1210-20.

165. Hughes CL, Hill JK, Dytham C. Evolutionary trade-offs between reproduction and dispersal in populations at expanding range boundaries. Proc R Soc Lond B Biol Sci. 2003;270(Suppl 2):S147-50.

166. Copilaş-Ciocianu D, Petrusek A. The southwestern Carpathians as an ancient Centre of diversity of freshwater gammarid amphipods: insights from the Gammarus fossarum species complex. Mol Ecol. 2015;24(15):3980-92.

167. Hou Z, Fu J, Li S. A molecular phylogeny of the genus Gammarus (Crustacea: Amphipoda) based on mitochondrial and nuclear gene sequences. Mol Phylogenet Evol. 2007;45(2):596-611.

168. Adams NE, Inoue K, Seidel RA, Lang BK, Berg DJ. Isolation drives increased diversification rates in freshwater amphipods. Mol Phylogenet Evol. 2018; 127:746-57.

169. Agrawal AA. Phenotypic plasticity in the interactions and evolution of species. Science. 2001;294(5541):321-6.

170. Lee CE, Remfert JL, Gelembiuk GW. Evolution of physiological tolerance and performance during freshwater invasions. Integr Comp Biol. 2003;43(3):439-49.

171. Falconer DS. Introduction to quantitative genetics. Edinburgh: Oliver and Boyd; 1960.

172. Ingersoll C, Ankley G, Burton G, Dwyer F, Hoke R, Norberg-King T, Winger $P$. Methods for measuring the toxicity and bioaccumulation of sediment-associated contaminants with freshwater invertebrates. In: US Environmental Protection Agency; 1994.

173. Weston DP, Poynton HC, Wellborn GA, Lydy MJ, Blalock BJ, Sepulveda MS, Colbourne JK. Multiple origins of pyrethroid insecticide resistance across the species complex of a nontarget aquatic crustacean Hyalella azteca. Proc Natl Acad Sci. 2013;110(41):16532-37.

174. Reznick DN, Shaw FH, Rodd FH, Shaw RG. Evaluation of the rate of evolution in natural populations of guppies (Poecilia reticulata). Science. 1997;275(5308):1934-7.

175. Reznick DA, Bryga H, Endler JA. Experimentally induced life-history evolution in a natural population. Nature. 1990;346(6282):357-9.

\section{Publisher's Note}

Springer Nature remains neutral with regard to jurisdictional claims in published maps and institutional affiliations.
Ready to submit your research? Choose BMC and benefit from:

- fast, convenient online submission

- thorough peer review by experienced researchers in your field

- rapid publication on acceptance

- support for research data, including large and complex data types

- gold Open Access which fosters wider collaboration and increased citations

- maximum visibility for your research: over $100 \mathrm{M}$ website views per year

At BMC, research is always in progress.

Learn more biomedcentral.com/submissions 